\title{
Assessing Public Awareness of the Economic, Environmental, and Social Impacts of the COVID-19 Pandemic in Malaysia
}

Nitanan Koshy Matthew, Ahmad Shuib, Velan Kunjuraman, Jeffrey Lawrence D'Silva Alby and Sharifah Intan Sharina Syed Abdullah

To Link this Article: http://dx.doi.org/10.6007/IJARBSS/v11-i11/11270 DOI:10.6007/IJARBSS/v11-i11/11270

Received: 05 September 2021, Revised: 28 September 2021, Accepted: 21 October 2021

Published Online: 09 November 2021

In-Text Citation: (Matthew et al., 2021)

To Cite this Article: Matthew, N. K., Shuib, A., Kunjuraman, V., Alby, J. L. D., \& Abdullah, S. I. S. S. (2021). Assessing Public Awareness of the Economic, Environmental, and Social Impacts of the COVID-19 Pandemic in Malaysia. International Journal of Academic Research in Business and Social Sciences, 11(11), $433-466$.

\section{Copyright: @ 2021 The Author(s)}

Published by Human Resource Management Academic Research Society (www.hrmars.com) This article is published under the Creative Commons Attribution (CC BY 4.0) license. Anyone may reproduce, distribute, translate and create derivative works of this article (for both commercial and non-commercial purposes), subject to full attribution to the original publication and authors. The full terms of this license may be seen at: http://creativecommons.org/licences/by/4.0/legalcode

Vol. 11, No. 11, 2021, Pg. $433-466$ 


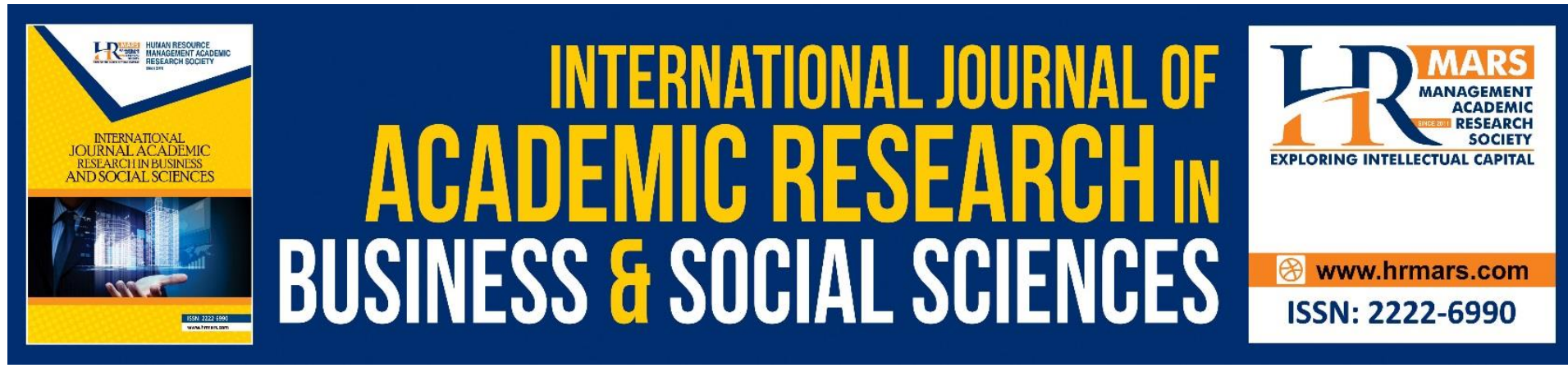

\title{
Assessing Public Awareness of the Economic, Environmental, and Social Impacts of the COVID- 19 Pandemic in Malaysia
}

\author{
Nitanan Koshy Matthew ${ }^{1,2}$, Ahmad Shuib33, Velan Kunjuraman ${ }^{4}$, \\ Jeffrey Lawrence D'Silva Alby ${ }^{5}$ and Sharifah Intan Sharina \\ Syed Abdullah 6 \\ ${ }^{1}$ Department of Environment, Faculty of Forestry and Environment, Universiti Putra \\ Malaysia,43400 Serdang, Selangor, Malaysia, ${ }^{2}$ Institute of Tropical Agriculture and Food \\ Security (ITAFoS), Universiti Putra Malaysia, 43400 UPM, Serdang, Selangor, Malaysia, \\ ${ }^{3}$ Faculty of Economics and Management, Universiti Putra Malaysia, 43400 UPM Serdang, \\ Selangor, Malaysia, ${ }^{4}$ Faculty of Hospitality, Tourism and Wellness, Universiti Malaysia \\ Kelantan, 17600 Jeli, Kelantan, Malaysia, 5IPSAS Institut Pengajian Sosial, Universiti Putra \\ Malaysia, 43400 Serdang, Selangor, Malaysia, ${ }^{6}$ Department of Foundations of Education, \\ Faculty of Educational Studies, Universiti Putra Malaysia, 43400 Serdang, Selangor, Malaysia \\ Email: nitanankoshy@upm.edu.my,mad.shuib@gmail.com, velan1199@gmail.com, \\ jld@upm.edu.my, sharifahintansharina@upm.edu.my
}

\begin{abstract}
Due to the fact that COVID-19 is a novel viral infection, there is no pre-existing immunity in humans, and everyone is presumed to be a susceptible host. Therefore, public awareness of the COVID-19 pandemic's impacts on Malaysia remains unclear for decision-making purposes. Hence, this study sought to ascertain the level of public awareness about the economic, environmental, and social implications of the COVID-19 pandemic. The instrument, a google form questionnaire, was developed in response to previous studies. For data analysis, a total of 437 completed responses were obtained. The data analysis process used both descriptive and inferential statistical techniques. The findings indicated that respondents reported a significant influence of the COVID-19 pandemic on Malaysia's local economy, environment, and social aspects. Additionally, the economic effect varied significantly among age groups, income categories, and residential areas. The socio-economic crisis altered investment patterns and had a profound impact on both the economic and social sectors. Therefore, it is necessary to understand the socio-economic implications of COVID-19 and to develop comprehensive socio-economic preparations to maintain Malaysia's social, environmental, and economic sustainability during and after the pandemic. This study delved into critical COVID-19 responses and society's lessons learned in order to keep Malaysian authorities, businesses, and industry informed.
\end{abstract}

Keywords: Awareness, COVID-19, Economic, Environment, Impacts, Social 


\section{Introduction}

SARS-CoV-2 is the most recent member of the human coronavirus family that causes COVID19. Due to the fact that this is a novel viral infection, there is no pre-existing immunity in humans, and everyone is presumed to be a COVID-19 susceptible host (Xu et al., 2020). Such transmission occurred most often at the household level, with family clusters accounting for 78 per cent to 85 per cent of disease clusters (WHO, 2020). Worldwide transmissions are probable due to the novel virus's moderately high infectivity, mild clinical symptoms in addition to the uncertain incubation period. Other factors are lack of human immunity and the possibility of asymptomatic healthy carriers. According to most analysts, the outbreak, mass quarantine, and worldwide travel restriction started to significantly impact the global economy by the end of January.

The coronavirus epidemic has had a detrimental effect on Malaysia's economy, particularly the tourism and travel industries. Malaysian authorities declared a loss of RM 3.4 billion in the first quarter of 2020 (Dzulkifly, 2020). It has been reported that travel and tours have been cancelled, causing turmoil for its hotels and airlines. The most visible consequence of the COVID-19 outbreak has been a decline in foreign visitors to Malaysia's most popular tourist destinations. As a result, Malaysian authorities forecast that the country's GDP will decline from 0.8 to 1.2 per cent (Karim et al., 2020). Malaysia's government now aims to compel a merger of the country's domestic carriers (Malaysia Airlines and low-cost Asia Airlines) in order to aid both airlines in the aftermath of the COVID-19 catastrophe. Malaysia's two largest airlines have taken a severe beating during the last several months.

Additionally, many other businesses have begun to suffer, particularly those that depend heavily on tourism. Companies have suspended travels and conferences, and governments have closed state borders as a result of travel restrictions and isolation. Thus, COVID-19's implications on economic, environmental, and social aspects of sustainability were unavoidable.

\section{Literature Review}

\section{Economic Impacts of COVID-19 in Malaysia}

As the infection progressed, the COVID-19 pandemic had far-reaching consequences on its own and as a result of all attempts to contain it. Due to the virus's global spread, various firms, from suppliers to manufacturers, have experienced increased anxiety and decreased clientele in the service sectors (Financial Times, 2020). As of February 2020, as a result of a significant increase in COVID-19 cases, stock markets suffered their worst weekly declines since the 2008 economic crisis (Smith, 2020). At the time, more than a third of the world's population was put under lockdown; as a result, the epidemic triggered the most prominent global recession in history (Kaplan et al., 2020).

Scarcity of supply is anticipated to affect various industries due to increased consumption of commodities, panic purchasing, and disruptions in production and transportation globally (Shah et al., 2020). Additionally, there have been several instances of deficiencies in pharmaceutical products (Barlas, 2013). Furthermore, numerous areas have experienced panic purchasing, resulting in shortages of critical grocery products and food. Additionally, the technological sectors have experienced delays in delivering electronic products (Barlas, 2013).

In March 2020, the worldwide stock market plummeted in several critical indicators. When the virus began to spread, international events and conferences involving fashion, technology, and sports activities were postponed or withdrawn (Edoho \& Mfon, 2020). 
Although the effect on the tourist sector cannot be assessed yet, it is projected to be in the billions and escalating (Edoho \& Mfon, 2020). In April 2020, the International Monetary Fund (IMF) declared that practically all of the nations had begun to face a "deep recession" and, consequently, the pandemic would cause a significant slowdown in economic development in developing countries (Fernandes, 2019). During the crisis, the world stock market suffered unprecedented volatility, primarily due to the severe ambiguity among the traders (Fernandes, 2019). The International Monetary Fund estimates that the recession due to the COVID-19 would be the most significant severe economic recession globally since the Great Depression and "far worse" than the Big Downturn in 2009 (Amon \& Wurth, 2020). In Malaysia, the COVID-19 recession is drastically impacting the macro-economy and the citizen's financial conditions. A key reason of economic recession in Malaysia is the newly enforced movement restriction order in order to slow down the infection of the coronavirus (Khan \& Naushad, 2020).

Prior to Malaysia's lockdown protocols, the novel virus had triggered widespread supply and demand concerns in China and around the globe. As Chinese demand decreased, exporters worldwide faced financial hardships and reduced pricing. In addition, manufacturers globally slashed output in response to China's factory closures. The effects of these shocks in China may be more severe in Malaysia, given the country's economy is strongly dependent on Chinese demand and supply. In addition, Malaysia is a significant trading partner of China, and China visitors are among the country's significant sources of tourism (Bastos, 2020).

Additionally, Malaysian businesses have been deeply integrated into global production networks. Thus, local supply chain systems have evolved more interconnected with international commerce over several decades, particularly in China. Indeed, when the global supply chain is disrupted, more than 20 billion dollars, or a quarter of the Malaysia-China trade in intermediate parts, would be impacted the most (Bastos, 2020). On the other hand, although enforcing the movement restriction order was essential to contain the novel COVID19 pandemic in Malaysia, it also incurred significant economic expenses (Karim et al., 2020). The closure of all businesses and local services, along with movement and travel restrictions, will profoundly affect private business investment (Bastos, 2020). The pandemic's adverse effects on an individual's livelihood and employment will be considerably more devastating. Small businesses impacted by the temporary shutdown will be more likely to face direct cash flow restrictions as revenues decline (Shah et al., 2020).

The World Tourism Organization estimates that between 100 and 120 million direct tourist employment is at stake globally (UNWTO, 2020). Since the COVID-19 pandemic's emergence, quarantines, entry bans, and other restrictions have been implemented globally, including Malaysian citizens. For instance, in Kuala Lumpur, the total number of employees is approximately 20,000 , with $16 \%$ facing compensation reductions, $20 \%$ facing unpaid leaves, and 3\% risking job loss. According to The Star Malaysia, the epidemic impacted over 56,000 hotel employees, with $9 \%$ receiving salary reductions, $17 \%$ having unpaid leaves indefinitely, and many experiencing layoffs (Zubair \& Shamsudin, 2021). Additionally, the majority of industries have been shuttered to cut down on transportation. One potential outcome of these initiatives is a decrease in industrial and transportation-related pollution, improving urban sustainability. Thus, the worldwide reaction to the COVID-19 outbreak has a substantial economic and social impact due to travel restrictions and a decline in travel readiness.

COVID-19 dissemination continues to represent a significant threat to public health and has a considerable economic effect in Malaysia. Worker displacement, business closures, and stock 
market collapses are just a few of the impacts of the pandemic's worldwide lockdown. COVID19 's influence, according to the International Monetary Fund (IMF), would result in a global economic downturn in 2021 and a fall in economic growth to 3 per cent (Farique\& Fauzi, 2021). COVID-19 impeded economic growth for two primary reasons. At initially, the worldwide epidemic's exponential rise directly led to financial and capital market instability. Additionally, severe restrictions on people mobility and transportation have drastically reduced tourist activity in Malaysia, placing a burden on both consumer and productive economic activity. However, the strict movement and commercial activity restrictions imposed by COVID-19 have led to an economic slowdown, which is expected to decrease environmental pollution (Ali, Parveen, Yaacob, Zaini \& Sarbini, 2021).

Most businesses in Malaysia are small and medium-sized enterprises (SMEs) operating in various areas and contributing significantly to the country's GDP (Khazaei, 2020). However, small and medium-sized businesses' financial resources may be depleted excessively, leaving vulnerable groups such as lower-income businesses, part-time and jobless individuals. These circumstances can have a disastrous effect on the economy as a whole, bankrupting people, burdening firms with debt, and burdening the financial system with loans.

The COVID-19 pandemic has posed significant hurdles to the United Nations' sustainable development objective of eradicating global poverty by 2030 (Sumner et al., 2020). For the first time since 1990, the global poverty level is increasing. This increase in poverty may result in a decades-long reversal of the worldwide effort to eradicate poverty (Sumner et al., 2020). In some nations, the adverse effect may result in poverty equivalent to those recorded 30 years ago (Sumner et al., 2020). One of the most critical insights learned is that swift and determined action may reverse a disaster. For example, South Korea implemented a government reform shortly after confirming its first COVID-19 cases, allowing domestic manufacturers to produce tests following WHO guidelines, allowing the nation to test hundreds of thousands of individuals. Singapore, too, has been able to "flatten the curve" or limit the incidence of infection by combining intensive contact tracking with a robust healthcare system. These nations have shown that swift action to control the coronavirus's spread may save lives (Fernandes, 2019).

\section{Environmental Impacts}

Prior to the COVID-19 pandemic, the globe faced the problem of lowering greenhouse gas emissions. The International Panel on Global Warming has cautioned that even a half-degree Celsius increase significantly increases the danger of flooding, drought, excessive temperature, and poverty for hundreds of millions of people. Climate change experts estimate that greenhouse gas (GHG) emissions will likely decline to a level not seen since World War II (Global Carbon Project, 2019). Carbon Dioxide, the primary greenhouse pollutant, is mainly generated by combustion engine automobiles in Malaysia and many other countries (Khazaei \& Tareq, 2021). The Malaysian government's movement restriction order and the social distancing protocols adopted by most countries have resulted in a worldwide decrease in carbon dioxide emissions (Anjum, 2020).

Most countries impacted by COVID-19 have adopted critical corrective measures, including lockdown, to combat the infection. Complete lockdown and sealing of hotspots have resulted in unnecessary mobility elimination (Singh \& Mishra, 2021). Additionally, total country isolation (Urban \& Nakada, 2021) and social isolation contributed to the breakup of the COVID-19 transmission chain. The lockdown has been proven to be the most effective technique of avoiding COVID-19 transmission as it eliminates person-to-person interaction 
(Singh \& Mishra, 2021). Between 25th March and 31st May 2020, the Indian government implemented a national lockdown in four phases during the early stages of COVID-19 dissemination. The Indian government put limitations on several economic activities, transportation modes, tourist locations, and superfluous human mobility throughout this period. River water quality has deteriorated as a result of the cessation of several industrial activities throughout the lockdown period (Straka al., 2021).

Additionally, throughout the lockdown period, noise and air pollution were decreased as a consequence of limited vehicle mobility and the closure of coal and gas-fired power plants (Rasheed, Rizwan, Javed, Sharif \& Zaidi, 2021). It has been reported that during the shutdown period, greenhouse gas levels decreased for the first time since World War II. Furthermore, air pollution levels in industrial cities decreased during the lockdown period (Singh \& Mishra, 2021). On the other hand, this pandemic enhanced air and water quality and had some negative implications, such as the formation of massive volumes of hospital and household rubbish and disturbance of the solid waste recycling process. Apart from these environmental repercussions, the COVID-19 pandemic impacted the Sustainable Development Goals (SDGs) (Straka al., 2021).

Air pollution has fallen dramatically in Europe since officials advised citizens to remain at home to halt the spread of the virus. As a result, numerous industries have come to a halt (Anjum, 2020). In addition, numerous beaches across the globe have been cleaner as a consequence of the reduction in rubbish left by beach visitors. Similarly, noise levels have decreased dramatically in the majority of countries. The decline in private and public transportation and economic activity has resulted in a noise reduction.

Due to the lack of visitors and public distancing actions resulting from the epidemic, attendance in several coastal areas throughout the globe has decreased. Beaches seem to have regained their pristine waters (Zambrano-Monserrate et al., 2020). Organic and nonorganic waste generation directly contributes to various environmental concerns, including deforestation, soil erosion, and air and water pollution (Mourad, 2016; Schanes et al., 2018). Due to the quarantine processes implemented in most nations, consumers have shifted to online shopping, resulting in a rise in domestic organic waste. Medical waste has also risen dramatically in the outbreak's aftermath. In countries like the United States of America, waste from personal protective equipment such as gloves and masks has increased significantly (Calma, 2020).

\section{Social Impacts}

The world is experiencing catastrophic health and financial crises, unparalleled in the United Nations' history. It is a social, economic, and communal disaster of unprecedented proportions. The Coronavirus epidemic is also wreaking havoc on communities. Early indications show that the COVID-19 epidemic has already impacted every segment of the global population (Duan \& Zhu, 2020).

Additionally, according to the International Labour Organization (ILO), tourism employed 10.3 per cent of the global workforce in 2019 (International Labour Organization, 2020) The virus's effect on people's health and economy is disproportionate and disproportionately affects poorer residents. For example, homeless persons may be unable to find refuge in a safe location. As a result, they would be especially vulnerable to the deadly infection. Families without access to safe drinking water, migrants, refugees, and internally displaced persons may also be disproportionately harmed, both by the virus and by the infection's resultant: reduction in employment opportunities. 
In the long run, the societal problems generated by the COVID-19 epidemic have intensified marginalisation, inequality, and global redundancy (Holmes et al., 2020). Social distancing protocols have also interrupted a variety of daily activities, including sports and physical pursuits. The challenges that have arisen in the aftermath of COVID-19 have affected sports, physical activities, in addition to people's well-being. Coronavirus infection has the potential to have a tremendous impact on one's psychological well-being. There is evidence that suicidal behaviour is increasing (Holmes et al., 2020). Suicide is predicted to become a more substantial concern as the illness progresses and has long-term effects on the economy, a large population, and vulnerable individuals (Gunnell et al., 2020).

Healthcare workers' excessive workloads and stress-related symptoms predispose them to mental discomfort, which increases their chance of developing psychiatric syndromes (Chatzittofis et al., 2021). Meanwhile, healthcare personnel and physicians, particularly those working in emergency departments, will experience physical and emotional weariness. As a result, feelings of uncertainty and uncertainty brought on by a virus may affect their careers and relationships (Chatzittofis et al., 2021).

Additionally, as the virus spreads, there is a danger of the proliferation of conspiracies and misrepresentations regarding the virus's origin and nature, as well as governments' efforts to control it. However, research by Holmes et al. (2020) found that conspiracy theories have not grown in nations in response to these public fears about the epidemic, and societies have improved their faith in their governments and organisations. Globally, the COVID-19 pandemic has had a profound effect on economic sectors. However, the social and environmental consequences of COVID-19 on global societies must be investigated as well. Additionally, the economic implications of the COVID-19 epidemic have left a negative legacy and harmed the country's income. For example, a letter issued by Malaysia's current Prime Minister on 9th March 2020 said that the outbreak of COVID-19 has cost the country's tourist sector an estimated RM3.37 billion in the first two months of 2020. Consequently, Malaysia's gross domestic product (GDP) growth for 2020 is at risk of shrinking by as much as 0.8 to 1.2 percentage points, amounting to a possible loss of up to RM17.3 billion (Dzulkifly, 2020). This is a significant economic loss for the country, exacerbated by the COVID-19 epidemic, and the economic ramifications for the future remain unknown.

COVID-19 has resulted in a slew of unexpected consequences, most notably economic turmoil, health difficulties, and social survival, all of which have impacted global populations. These effects are still being experienced, prompting social concern among scholars to take this topic seriously. However, there is a dearth of empirical research about the COVID-19's influence on the livelihoods of local populations. Numerous studies have been published, most of which concentrate on the COVID-19's impact on the tourist and hospitality industries (Foo et al., 2020; Karim et al., 2020), with little emphasis on public knowledge of the problem. Public awareness of the economic, social, and environmental consequences of COVID-19 is critical for determining their preparedness and coping measures. Thus, the purpose of this research was to ascertain the degree of understanding about the COVID-19 pandemic's economic, environmental, and social impacts. This entailed establishing links between the three factors and analysing the disparities between the socio-demographic variables and the three indicated effects. The study's conclusions have ramifications for both the policy and academic worlds. 


\section{Research Methodology}

\section{Survey Subjects and Data Collection}

The data for this study's empirical analysis were obtained utilising well-structured questionnaires to obtain primary data from 437 residents through a survey technique. This study employed a self-administered technique using an online questionnaire to collect primary data from Malaysian aged over 18 years old. The Google forms questionnaire was constructed and disseminated to several groups on WhatsApp, Facebook, and email based on the convenient sampling technique. The questionnaire was divided into four sections. Section A contains socio-demographic information of the respondents; Section B contains 18 items regarding the economic effects of COVID-19; Section C contains 15 items about the environmental impacts of COVID-19; and Section D contains 12 items about the social impacts of COVID-19. A reliability test was conducted on the questionnaire's Likert scale questions in Sections B, C, and D. Cronbach's alpha for Section B was 0.84, for Section C, it was 0.915, and for Section D, it was 0.899. According to Nunnally and Bernstein (1978), a minimum Cronbach's alpha value of 0.7 is required. As a consequence of these dependability findings, the questionnaire may be employed for the research project.

The questionnaire was constructed after a review of previous research that served as the foundation for the addition of many new items. As a consequence, a standardised technique was established. It was separated into three phases: a comparative review of research on COVID-19's socio-economic and environmental effects (i.e., Obi et al., 2020; Shammi, BodrudDoza, Islam \& Rahman, 2020; Rousseau \& Deschacht, 2020), consultation with subject-matter experts and the execution of a pilot study.

The validity of an instrument is intrinsically tied to the manner in which it assesses the criteria for validity (Perroca \& Gaidzinski, 1998). Thus, the instrument is legitimate if its design and application allow it to measure the goal correctly. Assessment methods are commonly validated using the methodologies of content validity, face validity, criteria validity, and construct validity (Perroca \& Gaidzinski, 1998). This instrument's content validity, construct validity, reliability, criterion validity, and sensitivity were evaluated. In the first validation stage, the instrument was to establish its content validity, which included assessing its language clarity, practical application, and theoretical significance. This verification was conducted by evaluators of three university professors selected for their subject-matter competence following the authors' protocols (Cassepp-Borges, Balbinotti \& Teodoro, 2010). The instrument was presented to judges with Doctoral degrees in the respective area of study serving as evaluators. They assessed the theoretical significance of each question on the instrument. Each question was evaluated using a five-point Likert scale to determine the indicator's degree of validity. Recommendations for improvements were sought for items with a score of less than three. The instrument indicated sufficient to excellent content validity, according to the evaluating judges. Items with a rating of fewer than three stars were excluded. Following content validation, a pilot test was done with a sample of 30 cases from the study population to ascertain the research's design's feasibility and the instrument's clarity. The correlation matrix was utilised to assess the instrument's construct validity by illustrating the correlations between the pairs of variables. Pearson's correlation was employed throughout the instrument's test-retest stage. All scale values with a less than 0.05 significance level were excluded (Everitt, Skrondal, 2010).

Pearson's correlation is too sensitive to outliers; it is also affected by the slope around which points are grouped, curvature, the amplitude of the residuals, range restriction, and heteroscedasticity. This study calculates an additional robust correlation: the Spearman's rho 
(Seth \& Housseini, 2014). These variants to Pearson's correlation have practical usefulness as they estimate linear correlations and frequently provide more accurate estimates of the underlying relationship between variables (Rousselet and Pernet, 2012). With regard to the overall structure of the data, Spearman's estimates linear connections besides the Pearson's correlation coefficients with comparable results between the [-1 and +1] range. By considering the overall structure of the data, Spearman's rank correlation coefficient (Spearman's rho) analysis revealed significant correlations, which were a direct mirror of Pearson's correlation (Seth \& Housseini, 2014).

The research questionnaire was then finalised. The questionnaire was presented in both Malay and English for the respondents' convenience.

The target respondents were determined following a sampling formula by Christensen et al. (2014) (Table 1).

Table 1: Sample sizes for various populations following the Christensen sample size table (2014)

\begin{tabular}{|c|c|c|c|c|c|c|c|c|c|}
\hline$N$ & $\boldsymbol{N}$ & $\boldsymbol{N}$ & $n$ & $N$ & $n$ & $N$ & $N$ & $N$ & $n$ \\
\hline 10 & 10 & 130 & 97 & 250 & 152 & 950 & 274 & $\begin{array}{l}10,00 \\
0\end{array}$ & 370 \\
\hline 20 & 19 & 140 & 103 & 260 & 155 & 1,000 & 278 & $\begin{array}{l}20,00 \\
0\end{array}$ & 377 \\
\hline 30 & 28 & 150 & 108 & 270 & 159 & 1,100 & 285 & $\begin{array}{l}30,00 \\
0\end{array}$ & 379 \\
\hline 40 & 36 & 160 & 113 & 280 & 162 & 1,200 & 291 & $\begin{array}{l}40,00 \\
0\end{array}$ & 380 \\
\hline 50 & 44 & 170 & 118 & 290 & 165 & 1,300 & 297 & $\begin{array}{l}50,00 \\
0\end{array}$ & 381 \\
\hline 60 & 52 & 180 & 123 & 300 & 169 & 1,400 & 302 & $\begin{array}{l}75,00 \\
0\end{array}$ & 382 \\
\hline 70 & 59 & 190 & 127 & 400 & 196 & 1,500 & 306 & $\begin{array}{l}100,0 \\
00\end{array}$ & 384 \\
\hline 80 & 66 & 200 & 132 & 500 & 217 & 2,000 & 322 & $\begin{array}{l}250.0 . \\
00\end{array}$ & 384 \\
\hline
\end{tabular}

Note: $N$ denotes the population size. $n$ denotes the recommended sample size.

However, instead of 384 respondents, an additional 53 were considered, bringing the total to 437 respondents and ensuring statistically robust findings.

\section{Analytical Methods}

The descriptive data analysis summarised the raw data and categorised them into less complicated metrics that indicated the complete data set. Descriptive analyses included frequency distributions; measures of central tendencies, such as mean, median, and mode; and variability (spread) measures, such as variance, standard deviation (SD), and the cross-tabulation technique. Moreover, an inferential analysis was conducted using the Statistical Package for Social Sciences 25.0. (SPSS 25.0). Inferential 
analyses such as the correlation test, Pearson chi-square test, Independent Sample T-test, and ANOVA were performed to accomplish the study's objectives.

\section{Data Analysis and Discussions}

According to Table 2, the majority of respondents were female (68.2 per cent). Following that, most of them were under 30 years old and were single (71.9 per cent ). In terms of education, 86.1 per cent held at least a degree. The majority (59.7 per cent) were students, followed by 21.1 per cent public sector employees and 10.3 per cent private sector employees. Following that, when it came to monthly gross household income, the majority of them (60 per cent) came from the B40 category. Additionally, 46.9 per cent of respondents resided in urban areas, 30.9 per cent in rural areas, and 22.2 per cent in suburban areas. On the other hand, the vast majority of them (89 per cent) were from West Malaysia (Peninsular Malaysia), while 11\% were from East Malaysia (Sabah and Sarawak), with Selangor recording the most significant percentage (27.2 per cent).

Table 2: Respondents' socio-demographic attributes

\begin{tabular}{|c|c|c|c|}
\hline & & Frequency & $\begin{array}{l}\text { Per } \\
\text { cent }\end{array}$ \\
\hline \multirow[t]{3}{*}{ A1. Gender } & Male & 139 & 31.8 \\
\hline & Female & 298 & 68.2 \\
\hline & Total & 437 & 100.0 \\
\hline \multirow[t]{5}{*}{ A2. Age } & Below 30 & 301 & 68.9 \\
\hline & $30-39$ & 62 & 14.2 \\
\hline & $40-49$ & 50 & 11.4 \\
\hline & Above 49 & 24 & 5.5 \\
\hline & Total & 437 & 100.0 \\
\hline \multirow{4}{*}{$\begin{array}{l}\text { A3. Marital } \\
\text { status }\end{array}$} & Single & 314 & 71.9 \\
\hline & Married & 119 & 27.2 \\
\hline & Divorced & 4 & .9 \\
\hline & Total & 437 & 100.0 \\
\hline \multirow{5}{*}{$\begin{array}{l}\text { A4. Education } \\
\text { level }\end{array}$} & Secondary school & 17 & 3.9 \\
\hline & STPM / Diploma & 44 & 10.1 \\
\hline & Degree & 325 & 74.4 \\
\hline & Master/PhD & 51 & 11.7 \\
\hline & Total & 437 & 100.0 \\
\hline \multirow{7}{*}{$\begin{array}{l}\text { A5. Employm } \\
\text { ent sector }\end{array}$} & Self-employed & 13 & 3.0 \\
\hline & Government sector & 92 & 21.1 \\
\hline & Private sector & 45 & 10.3 \\
\hline & Retired & 8 & 1.8 \\
\hline & Student & 261 & 59.7 \\
\hline & Unemployed & 18 & 4.1 \\
\hline & Total & 437 & 100.0 \\
\hline
\end{tabular}




\begin{tabular}{|c|c|c|c|c|c|}
\hline & & & & Frequency & $\begin{array}{l}\text { Per } \\
\text { cent }\end{array}$ \\
\hline \multirow{4}{*}{$\begin{array}{l}\text { A7. Total } \\
\text { gross } \\
\text { househol } \\
\text { d income } \\
\text { per } \\
\text { month }\end{array}$} & \multicolumn{3}{|c|}{ B40 (less than RM4,360) } & 262 & 60.0 \\
\hline & \multicolumn{3}{|c|}{ M40 (RM 4,360 - RM 9,619) } & 123 & 28.1 \\
\hline & \multicolumn{3}{|c|}{ T20 (more than RM 9,619) } & 52 & 11.9 \\
\hline & \multicolumn{3}{|l|}{ Total } & 437 & 100.0 \\
\hline \multirow{4}{*}{$\begin{array}{l}\text { A8. Location } \\
\text { of } \\
\text { residence }\end{array}$} & \multicolumn{3}{|l|}{ Urban } & 205 & 46.9 \\
\hline & \multicolumn{3}{|c|}{ Suburbs } & 97 & 22.2 \\
\hline & \multicolumn{3}{|l|}{ Rural } & 135 & 30.9 \\
\hline & \multicolumn{3}{|l|}{ Total } & 437 & 100.0 \\
\hline \multirow{16}{*}{$\begin{array}{l}\text { A10.State } \\
\text { currently } \\
\text { live in }\end{array}$} & \multirow{13}{*}{$\begin{array}{l}\text { West } \\
(389)\end{array}$} & \multirow{3}{*}{$\begin{array}{l}\text { Southern } \\
\text { Region (66) }\end{array}$} & Johor & 39 & 8.9 \\
\hline & & & Melaka & 13 & 3.0 \\
\hline & & & $\begin{array}{l}\text { Negeri } \\
\text { Sembilan }\end{array}$ & 14 & 3.2 \\
\hline & & \multirow{4}{*}{$\begin{array}{l}\text { Northern } \\
\text { Region (68) }\end{array}$} & Perak & 28 & 6.4 \\
\hline & & & Perlis & 6 & 1.4 \\
\hline & & & $\begin{array}{l}\text { Pulau } \\
\text { Pinang }\end{array}$ & 8 & 1.8 \\
\hline & & & Kedah & 26 & 5.9 \\
\hline & & \multirow{3}{*}{$\begin{array}{l}\text { Central } \\
\text { Region (146) }\end{array}$} & Putrajaya & 1 & 0.2 \\
\hline & & & $\begin{array}{l}\text { Kuala } \\
\text { Lumpur }\end{array}$ & 26 & 5.9 \\
\hline & & & Selangor & 119 & 27.2 \\
\hline & & East Coast & Terengganu & 32 & 7.3 \\
\hline & & \multirow[t]{2}{*}{ Region (105) } & Kelantan & 51 & 11.7 \\
\hline & & & Pahang & 22 & 5.0 \\
\hline & \multirow{2}{*}{$\begin{array}{l}\text { East } \\
(48)\end{array}$} & \multirow{3}{*}{$\begin{array}{l}\text { East Malaysia } \\
(51) \\
\text { tal }\end{array}$} & Sabah & 18 & 4.1 \\
\hline & & & Sarawak & 33 & 7.5 \\
\hline & Overall total & & Total & 437 & 100.0 \\
\hline
\end{tabular}

The respondents' awareness of economic consequences was assessed using a five-point Likert scale ( $1=$ Strongly Disagree to $5=$ Strongly Agree). The total mean score of 3.68 out of 5 was derived based on Table 3, suggesting a high level of agreement. Except for awareness of the COVID-19 pandemic's impact on "employment rate" (2.82), the COVID-19 pandemic "has created new business opportunities in Malaysia" (3.24), "the value of properties in Malaysia has been affected by the COVID-19 pandemic outbreak" (3.38), and the COVID-19 pandemic "has affected the country's economy" (3.44), the COVID-19 outbreak's Movement Control Order (MCO) "has led to a disruption in the supply chains of products." (3.45), the COVID-19 pandemic outbreak "has led to in an increase in the prices of goods and services in Malaysia" (3.58), "The Malaysia currency exchange has been affected by the COVID-19 pandemic 
outbreak" (3.59), and "Moratorium facilities offered by banking institutions during the MCO have significantly affected people's finances" (3.62).

The item "The COVID-19 pandemic has impacted people's buying behaviours" had the highest mean (4.13). This finding corroborated the study conducted by Alam (2020), which identified the significant effects of the COVID-19 pandemic on a consumer's online purchasing behaviour. Catastrophes such as pandemics have economic impacts, as well as dramatic shifts in business and customer behaviours (Baker et al., 2020). Thus, even if emergent outbreaks cannot be wholly avoided, businesses and governments should be prepared to mitigate their harmful effects on communities. The item of COVID-19 impacts on "expenditure on cleanliness measures at workplaces" had the second-highest score (4.08), followed by "significant effect to people's savings" (4.03) and "causes of most severe impacts on SMEs" (4.02).

Outbreaks have historically had a detrimental effect on companies and society via adjustments in staffing policies, inefficiency in labour outcomes, and increased corporate and government expenditure on health care programmes and safety measures (McKibbin \& Fernando, 2020). According to Coibion et al. (2020), participants experienced a high level of insecurity, a decline in employment, a decline in consumer spending, and a decline in overall company expenditures.

The COVID-19 pandemic has had a direct impact on income due to massive business closure and decreased productivity. Additionally, it has triggered a negative supply shock, as industrial production has slowed as a consequence of global supply chain disruptions and facility closures (Tahajuddin \& Sulaiman, 2021). Equities on Malaysia's Bursa Malaysia exchange plummeted during the outbreak as investors liquidated their securities in anticipation of the virus's economic impact, which is predicted to persist until June 2020 in Malaysia and other emerging stock markets (Ramli \& Jamri, 2021). Malaysia's economy suffered directly as a result of China being the country's largest trade partner, and economic experts have warned that a protracted viral epidemic might have a severe effect on the country's gross domestic product (GDP) (Khatib \& Nour, 2021). Aberdeen Standard Investments of Malaysia also forecasted that the Malaysian ringgit (MYR) would depreciate more due to the local and global pandemic, which would have ramifications for the Malaysian political problem in 2021 (Ramli \& Jamri, 2021). In the second quarter of 2021, Malaysia's gross domestic product (GDP) contracted by 3.4 per cent. Furthermore, Malaysia's GDP contracted by 5.6 per cent in 2020, the lowest level since the Asian Financial Crisis in 1998 (Mark, Domingo \& Singh, 2021).

Bartik et al. (2020) evaluated the financial impact of the COVID-19 pandemic on over 6000 small and medium-sized enterprises (SMEs). The data indicated that the majority of SMEs were economically vulnerable barely a few weeks after the epidemic began. Additionally, the data highlighted experts' expectations for the long-term effects of the coronavirus pandemic on companies and economies worldwide. However, the duration and severity of the impacts will be contingent on governments' ability to properly execute preventative measures to curb the spread of the virus. Following that, it will be critical for governments to develop policies to address cash flow and supply chain challenges, particularly for SMEs, in order to protect employment and ease economic stress. Additionally, it is critical to understand how organisations' management systems have reacted to recent lockdowns and supply chain disruptions (Bartik et al., 2020). 
Table 3: The economic impacts of the COVID-19 pandemic

\begin{tabular}{|c|c|c|c|c|c|c|c|}
\hline \multirow[t]{2}{*}{ Statement } & \multicolumn{5}{|c|}{ Scale of Importance } & \multirow[t]{2}{*}{ Average } & \multirow[t]{2}{*}{ Level } \\
\hline & 1 & 2 & 3 & 4 & 5 & & \\
\hline $\begin{array}{l}\text { B1. The COVID- } \\
19 \text { pandemic } \\
\text { has affected } \\
\text { the economy } \\
\text { of the } \\
\text { country. }\end{array}$ & $\begin{array}{l}98 \\
(22.4 \%)\end{array}$ & $\begin{array}{l}50 \\
(11.4 \%)\end{array}$ & $\begin{array}{l}25 \\
(5.7 \%)\end{array}$ & $\begin{array}{l}88 \\
(20.1 \%)\end{array}$ & $\begin{array}{l}176 \\
(40.3 \%)\end{array}$ & 3.44 & 2 \\
\hline $\begin{array}{l}\text { B2. The COVID- } \\
19 \text { pandemic } \\
\text { has impacted } \\
\text { people's } \\
\text { buying } \\
\text { behaviours }\end{array}$ & $\begin{array}{l}21 \\
(4.8 \%)\end{array}$ & $\begin{array}{l}11 \\
(2.5 \%)\end{array}$ & $\begin{array}{l}43 \\
(9.8 \%)\end{array}$ & $\begin{array}{l}176 \\
(40.1 \%)\end{array}$ & $\begin{array}{l}186 \\
(42.6 \%)\end{array}$ & 4.13 & 3 \\
\hline $\begin{array}{l}\text { B3. The } \\
\text { Movement } \\
\text { Control } \\
\text { Order (MCO) } \\
\text { during the } \\
\text { COVID-19 } \\
\text { outbreak has } \\
\text { led to a } \\
\text { disruption in } \\
\text { the supply } \\
\text { chains of } \\
\text { products. }\end{array}$ & $\begin{array}{l}29 \\
(6.6 \%)\end{array}$ & $\begin{array}{l}52 \\
(11.9 \%)\end{array}$ & $\begin{array}{l}122 \\
(27.9 \%)\end{array}$ & $\begin{array}{l}161 \\
(36.8 \%)\end{array}$ & $\begin{array}{l}73 \\
(16.7 \%)\end{array}$ & 3.45 & 2 \\
\hline $\begin{array}{l}\text { B4. More } \\
\text { personal } \\
\text { financial } \\
\text { sources are } \\
\text { needed to } \\
\text { recover } \\
\text { personal } \\
\text { well-being. }\end{array}$ & $\begin{array}{l}15 \\
(3.4 \%)\end{array}$ & $\begin{array}{l}30 \\
(6.9 \%)\end{array}$ & $\begin{array}{l}77 \\
(17.6 \%)\end{array}$ & $\begin{array}{l}171 \\
(39.1 \%)\end{array}$ & $\begin{array}{l}144 \\
(33 \%)\end{array}$ & 3.91 & 3 \\
\hline $\begin{array}{l}\text { B5. The COVID- } \\
19 \text { pandemic } \\
\text { has created } \\
\text { new business } \\
\text { opportunities } \\
\text { in Malaysia. }\end{array}$ & $\begin{array}{l}44 \\
(10.1 \%)\end{array}$ & $\begin{array}{l}75 \\
(17.2 \%)\end{array}$ & $\begin{array}{l}117 \\
(26.8 \%)\end{array}$ & $\begin{array}{l}134 \\
(30.7 \%)\end{array}$ & $\begin{array}{l}67 \\
(15.3 \%)\end{array}$ & 3.24 & 2 \\
\hline
\end{tabular}


INTERNATIONAL JOURNAL OF ACADEMIC RESEARCH IN BUSINESS AND SOCIAL SCIENCES Vol. 11, No. 11, 2021, E-ISSN: 2222-6990 @ 2021 HRMARS

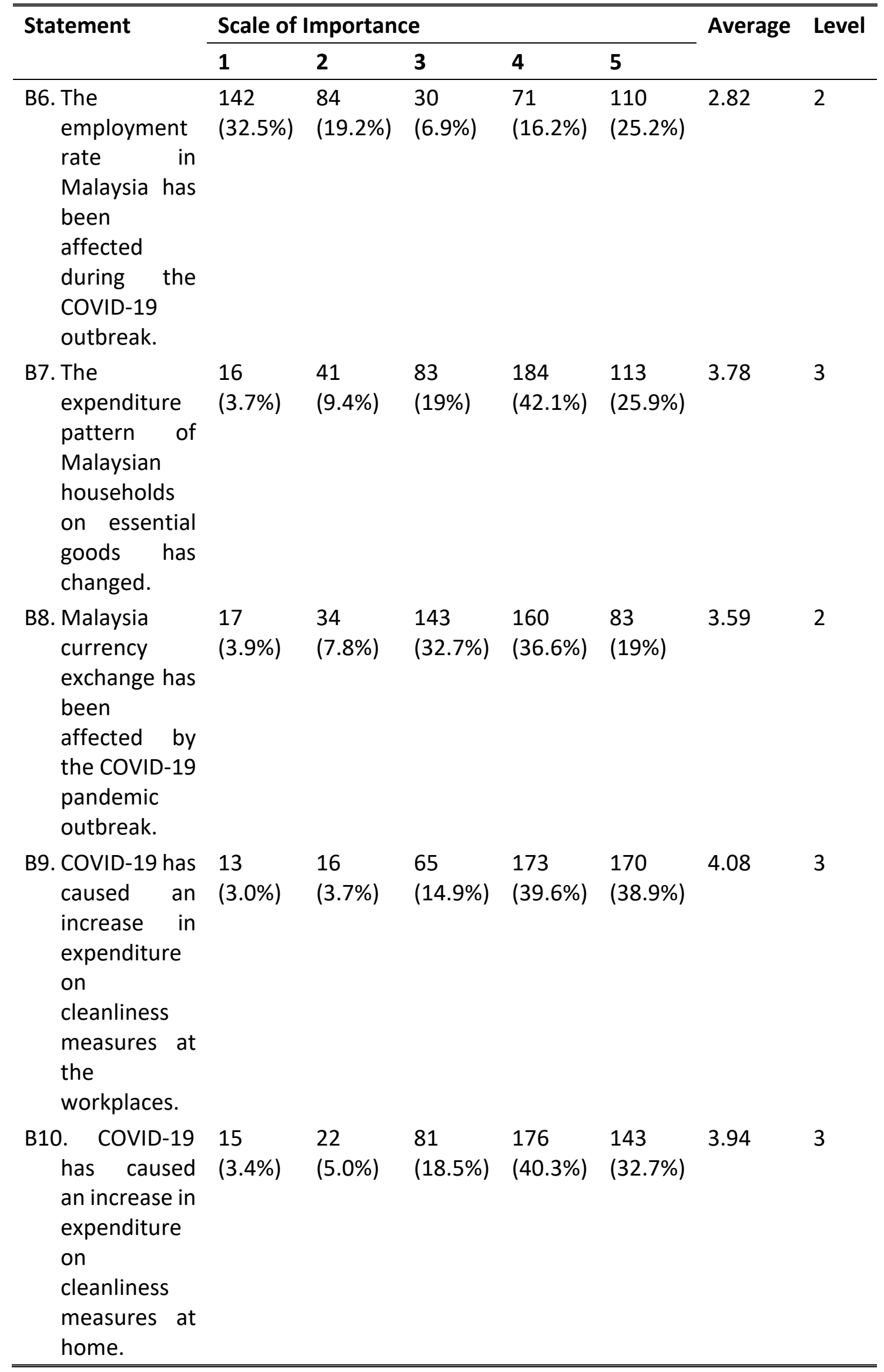


INTERNATIONAL JOURNAL OF ACADEMIC RESEARCH IN BUSINESS AND SOCIAL SCIENCES Vol. 11, No. 11, 2021, E-ISSN: 2222-6990 @ 2021 HRMARS

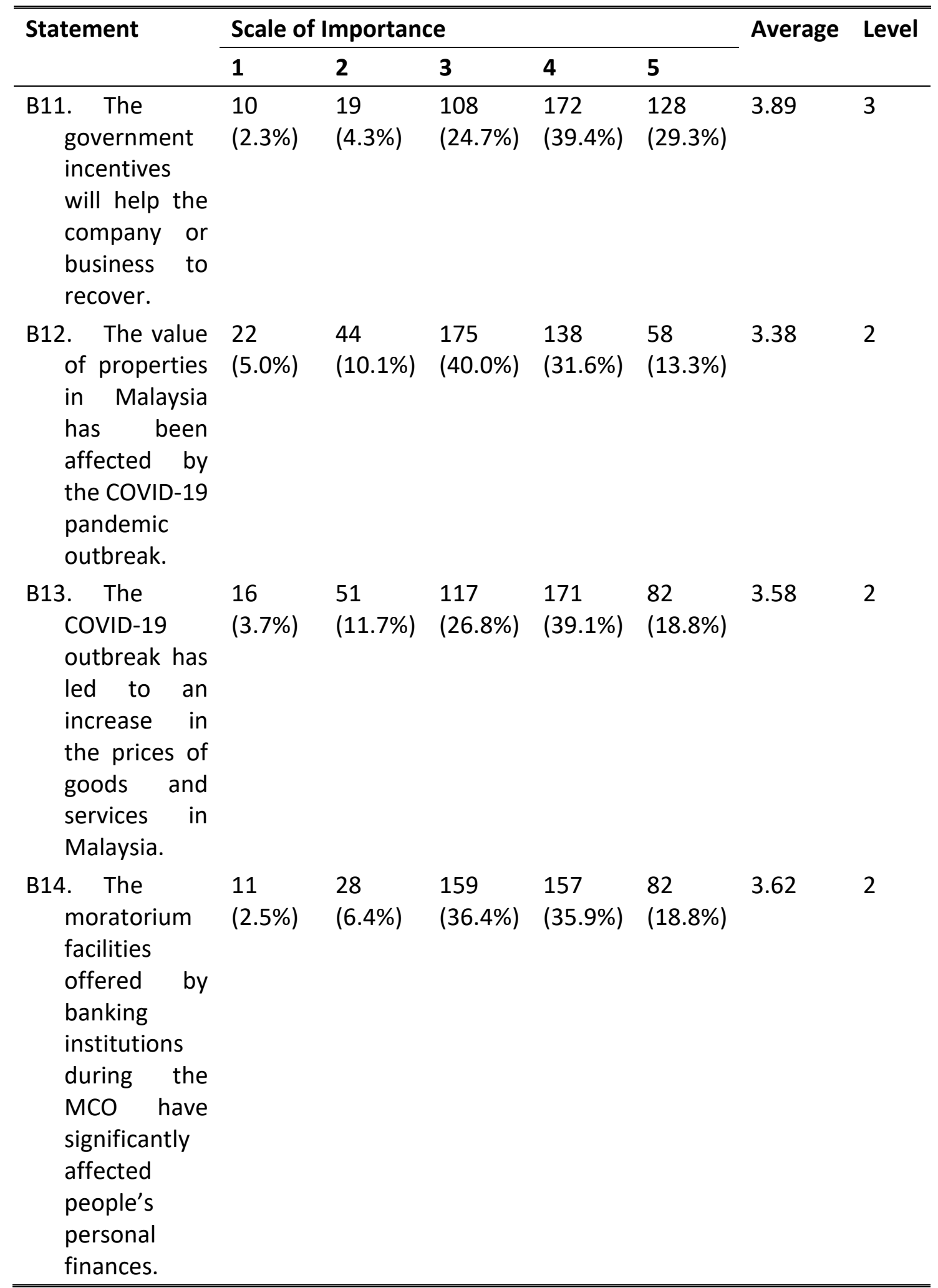




\begin{tabular}{|c|c|c|c|c|c|c|c|}
\hline \multirow[t]{2}{*}{ Statement } & \multicolumn{5}{|c|}{ Scale of Importance } & \multirow[t]{2}{*}{ Average } & \multirow[t]{2}{*}{ Level } \\
\hline & 1 & 2 & 3 & 4 & 5 & & \\
\hline $\begin{array}{l}\text { B15. The } \\
\text { situation } \\
\text { during the } \\
\text { outbreak has } \\
\text { significantly } \\
\text { affected } \\
\text { people's } \\
\text { savings. }\end{array}$ & $\begin{array}{l}11 \\
(2.5 \%)\end{array}$ & $\begin{array}{l}22 \\
(5.0 \%)\end{array}$ & $\begin{array}{l}62 \\
(14.2 \%)\end{array}$ & $\begin{array}{l}190 \\
(43.5 \%)\end{array}$ & $\begin{array}{l}152 \\
(34.8 \%)\end{array}$ & 4.03 & 3 \\
\hline $\begin{array}{l}\text { B16. The } \\
\text { COVID-19 } \\
\text { pandemic } \\
\text { has caused } \\
\text { most of the } \\
\text { severe } \\
\text { impacts on } \\
\text { SMEs. }\end{array}$ & $\begin{array}{l}14 \\
(3.2 \%)\end{array}$ & $\begin{array}{l}19 \\
(4.3 \%)\end{array}$ & $\begin{array}{l}75 \\
(17.2 \%)\end{array}$ & $\begin{array}{l}165 \\
(37.8 \%)\end{array}$ & $\begin{array}{l}164 \\
(37.5 \%)\end{array}$ & 4.02 & 3 \\
\hline Overall mean & & & & & & 3.68 & 3 \\
\hline
\end{tabular}

*Levels of agreement: low agreement (1): 1- 2.339, Medium agreement (2): 2.34-3.669, and High agreement (3): 3.67-5.00

The respondents' awareness of COVID-19's environmental effect was assessed using a fivepoint Likert scale ( 1 = Strongly Disagree to $5=$ Strongly Agree). According to Table 4 , an overall mean score of 4.0 out of 5 was achieved, falling below the standard of high agreement. Each item received a score above 3.0. The lowest scores were recorded for "Online working during the MCO period is more environmentally friendly" (3.52), the only item that fell into the second level, followed by "There has been an increase in waste generation due to an increase in medical waste" (3.73), and "There has been an increase in waste generation due to high demand for online shopping that requires packaging (3.79)."

The item "A cleaner environment is likely to have positive impacts on human health" had the highest mean score (4.33), followed by items C9 "Household electricity consumption has increased during the $\mathrm{MCO}$ " and C13 "Air quality has increased due to less transport movement on the road during the MCO". However, according to Gillingham et al. (2020), in the short run, due to the reduction in jet and combustion engine operations, the COVID-19 pandemic and its related measures have resulted in considerable reductions in carbon dioxide and other air pollutions in the US. Additionally, they argued that electricity demands decreased by less than 10 per cent (Gillingham et al., 2020).

Zambrano-Monserrate et al. (2020) investigated the indirect effects of the Coronavirus pandemic in countries such as the United States, Italy, and China. They asserted that the COVID-19 pandemic impacted the environment in both beneficial and detrimental ways. Their analysis found a substantial association between improvements in air quality, cleaner coastlines, and environmental noise reduction, as well as contingency measures.

The items "A cleaner environment will improve public environmental awareness among citizens (mean score: 4.18) and "The environment has healed naturally" (mean score: 4.12) both had high scores. Governments must provide a comprehensive overview of the 
contaminants associated with the epidemic. COVID-19 has resulted in macroplastic pollution. Thus, it is necessary to evaluate its potential effects on ecology and societal well-being (Patrício Silva et al., 2021). There must be a compromise between community health measures, including the widespread use of masks and other pollutant-eliminating goods, and environmental protection, as the two are inextricably linked. As a result, there is a need for increased public knowledge of this issue in order to enhance social assistance for more environmentally friendly consumption, paving the way for future economic recovery initiatives that are more sustainable (Rousseau \& Deschacht, 2020).

Particulate emissions, including black carbon and organic carbon, are associated with various activities, including transportation (which is disproportionately affected) and residential activities (which is disproportionately affected). Malaysia is less influenced by transmissionrelated air pollution emissions, material consumption, and land-use change, both short and long terms. For instance, biotic resources are less impacted by material consumption than air pollutants such as ammonia (NH3) (Najah et al., 2021). Land use has altered, most notably in terms of harvested area, which has shrunk (Adnan \& Nordin, 2021). However, the farmland area (harvested area) is practically unchanged in the short run. The relatively rapid recovery of food demand ensures that land-use change remains exceptionally close to baseline values (Adnan \& Nordin, 2021). This, together with the little impact on forestry, indicates that decreased economic activity may have minimal effect on biodiversity and environmental services (Najah et al., 2021).

Metals consumption is also linked to industrial activities, which have been affected less severely in the short term but have gradually begun to perform worse than other sectors; the immediate decrease is minor but growing over time. Non-metallic minerals will suffer in the near future as a result of 2020's precipitous decline in construction activities (Aw et al., 2021).

Table 4: The environmental impacts of the COVID-19 pandemic

\begin{tabular}{|c|c|c|c|c|c|c|c|}
\hline \multirow[t]{2}{*}{ Statement } & \multicolumn{5}{|c|}{ Scale of Importance } & \multirow[t]{2}{*}{ Average } & \multirow[t]{2}{*}{ Level } \\
\hline & 1 & 2 & 3 & 4 & 5 & & \\
\hline $\begin{array}{l}\text { C1. Air quality has } \\
\text { increased due } \\
\text { to less transport } \\
\text { movement on } \\
\text { the road during } \\
\text { the MCO. }\end{array}$ & $\begin{array}{l}15 \\
(3.4 \%)\end{array}$ & $\begin{array}{l}20 \\
(4.6 \%)\end{array}$ & $\begin{array}{l}46 \\
(10.5 \%)\end{array}$ & $\begin{array}{l}156 \\
(35.7 \%)\end{array}$ & $\begin{array}{l}200 \\
(45.8 \%)\end{array}$ & 4.16 & 3 \\
\hline $\begin{array}{l}\text { C2. There has been } \\
\text { an increase in } \\
\text { waste } \\
\text { generation due } \\
\text { to the high } \\
\text { demand for } \\
\text { online shopping } \\
\text { that requires } \\
\text { packaging. }\end{array}$ & $\begin{array}{l}12 \\
(2.7 \%)\end{array}$ & $\begin{array}{l}42 \\
(9.6 \%)\end{array}$ & $\begin{array}{l}112 \\
(25.6 \%)\end{array}$ & $\begin{array}{l}131 \\
(30.0 \%)\end{array}$ & $\begin{array}{l}140 \\
(32.0 \%)\end{array}$ & 3.79 & 3 \\
\hline
\end{tabular}




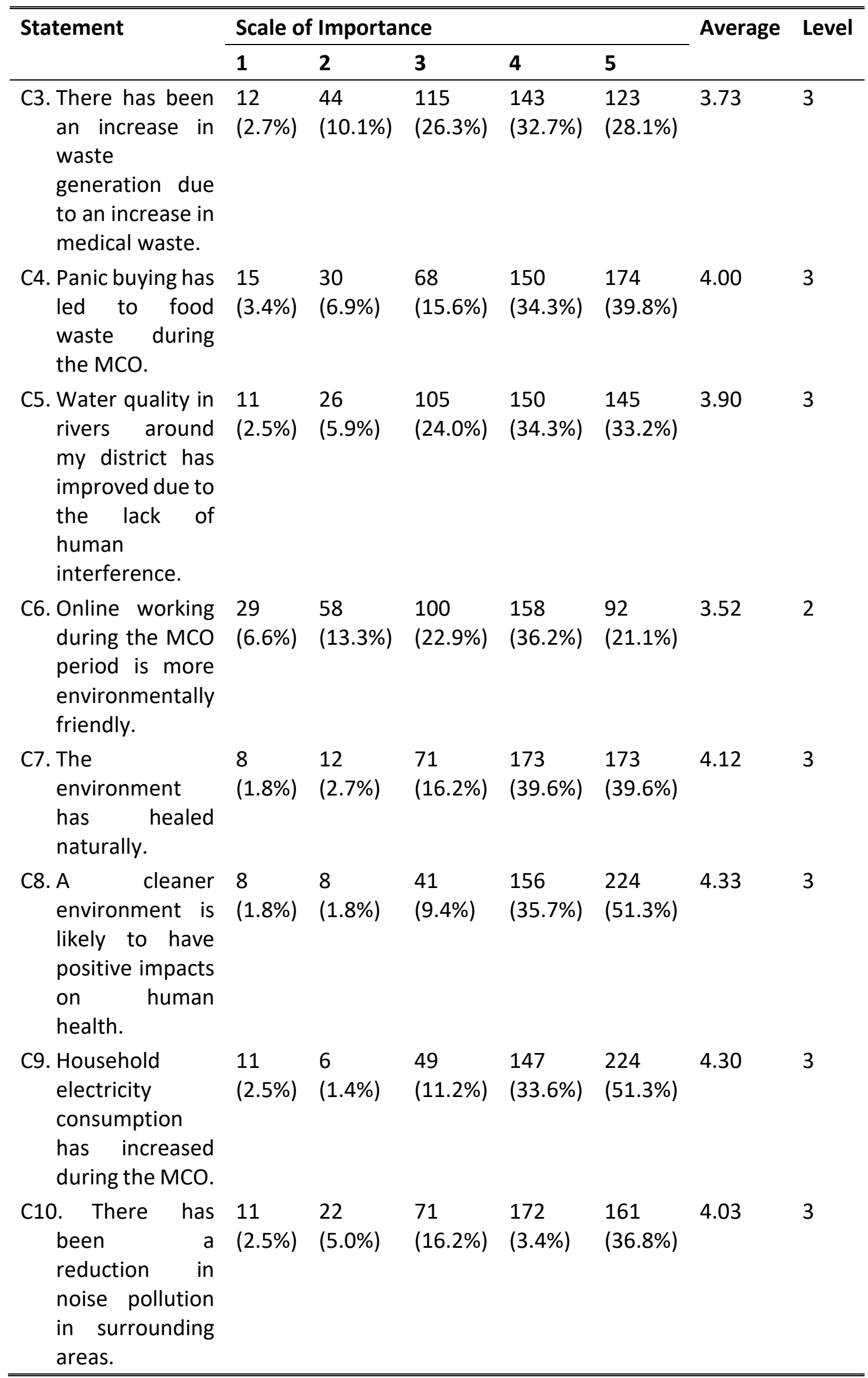




\begin{tabular}{|c|c|c|c|c|c|c|c|}
\hline \multirow[t]{2}{*}{ Statement } & \multicolumn{5}{|c|}{ Scale of Importance } & \multirow[t]{2}{*}{ Average } & \multirow[t]{2}{*}{ Level } \\
\hline & 1 & 2 & 3 & 4 & 5 & & \\
\hline $\begin{array}{l}\text { C11. The waste } \\
\text { production of } \\
\text { households has } \\
\text { increased } \\
\text { during the MCO. }\end{array}$ & $\begin{array}{l}12 \\
(2.7 \%)\end{array}$ & $\begin{array}{l}28 \\
(6.4 \%)\end{array}$ & $\begin{array}{l}84 \\
(19.2 \%)\end{array}$ & $\begin{array}{l}173 \\
(39.6 \%)\end{array}$ & $\begin{array}{l}140 \\
(32.0 \%)\end{array}$ & 3.92 & 3 \\
\hline $\begin{array}{l}\text { C12. Natural } \\
\text { resource } \\
\text { exploitations } \\
\text { are reduced } \\
\text { during this } \\
\text { pandemic. }\end{array}$ & $\begin{array}{l}10 \\
(2.3 \%)\end{array}$ & $\begin{array}{l}21 \\
(4.8 \%)\end{array}$ & $\begin{array}{l}107 \\
(24.5 \%)\end{array}$ & $\begin{array}{l}173 \\
(39.6 \%)\end{array}$ & $\begin{array}{l}126 \\
(28.8 \%)\end{array}$ & 3.88 & 3 \\
\hline $\begin{array}{l}\text { C13. A cleaner } \\
\text { environment } \\
\text { will improve } \\
\text { public } \\
\text { environmental } \\
\text { awareness } \\
\text { among the } \\
\text { citizens. }\end{array}$ & $\begin{array}{l}9 \\
(2.1 \%)\end{array}$ & $\begin{array}{l}17 \\
(3.9 \%)\end{array}$ & $\begin{array}{l}59 \\
(13.5 \%)\end{array}$ & $\begin{array}{l}154 \\
(35.2 \%)\end{array}$ & $\begin{array}{l}198 \\
(45.3 \%)\end{array}$ & 4.18 & 3 \\
\hline $\begin{array}{l}\text { C14. The COVID- } \\
19 \text { pandemic } \\
\text { has changed } \\
\text { people's } \\
\text { attitudes } \\
\text { towards nature. }\end{array}$ & $\begin{array}{l}7 \\
(1.6 \%)\end{array}$ & $\begin{array}{l}25 \\
(5.7 \%)\end{array}$ & $\begin{array}{l}103 \\
(23.6 \%)\end{array}$ & $\begin{array}{l}155 \\
(35.5 \%)\end{array}$ & $\begin{array}{l}147 \\
(33.6 \%)\end{array}$ & 3.94 & 3 \\
\hline Overall mean & & & & & & 4.00 & 3 \\
\hline
\end{tabular}

*Levels of agreement: Low agreement (1): 1- 2.339, Medium agreement (2): 2.34-3.669, and High agreement (3): 3.67-5.00

The respondents' awareness of the social consequences of COVID-19 was assessed using a five-point Likert scale ( 1 = Strongly Disagree to $5=$ Strongly Agree). According to Table 5 , an overall mean score was 3.90 out of 5 , indicating a high level of agreement in general. Except for the item assessing compliance with government-imposed rules aimed at controlling the spread of the COVID-19 pandemic, all item scores were within Level 3 (2.88). Item (D9) had the lowest mean score, indicating that the study's respondents believed that there was insufficient compliance with the measures in place to prevent the spread of the virus. Almost every government around the globe has declared or contemplated enacting social distancing and sanitation measures to contain the spread of Coronavirus contamination and mortality and alleviate the strain on health care professionals (Bavel et al., 2020). These restrictions include the cessation of meetings, activities, and school closure while encouraging workers to work from home (Driggin et al., 2020). Thus, the effectiveness of any procedure designed to halt an epidemic is mainly dependent on public compliance (Maharaj \& Kleczkowski, 2012). Briscese et al. (2020) found that numerous factors influence public compliance with COVID19 spreading measures, including awareness of the obligations, support and trust in 
governments, public awareness of the severity of the consequences of not following the measures, and awareness of the (financial and psychological) expenses of social distancing. This was followed by the item "food shortage has increased during the time of the COVID-19 pandemic outbreak" (3.05), item "whether the COVID-19 pandemic has hindered people from living a healthy lifestyle" (3.11), and COVID-19 pandemic "has affected people's mental health" (3.40), all of which were in level 2 (medium agreement). On the other hand, the item assessing if frontliners are the primary backbone in combating the COVID-19 pandemic (4.40) received the highest score, followed by determining if the COVID-19 pandemic has raised people's awareness of preparedness/readiness for future emergencies (4.37). The Coronavirus outbreak demonstrated that many countries' safety protocols for epidemic prevention and patient treatment in an effective healthcare system were not adequately established (Breitenbach et al., 2020). It is consequently critical to establish explicit guidelines for managing future outbreaks. In addition, it was an eye-opening reminder from the COVID19 pandemic about the vital need for public awareness and systematic preparation in order to avert the spread of this and other future viruses. As a result of this crisis, public awareness about how the virus spreads, the need for cleaning, and the avoidance of group meetings have increased (Merchant \& Lurie, 2020).

Additionally, it sent a powerful signal to governments and authorities about the critical nature of having access to medicinal essentials like sanitisers and masks in emergency circumstances. Thus, governments should develop strategic frameworks to forecast epidemic expansion to avert calamities like the current pandemic (Todorovic et al., 2020).

This was followed by the items indicating that the pandemic raised awareness of the critical nature of open communication about the COVID-19 pandemic's effects (4.33) and if the learning processes at schools/universities were interrupted as a result of the COVID-19 pandemic (4.32).

The findings indicated that Malaysians' preferences for meeting people have declined, with the most significant impact on future desires to meet less well-known individuals. The extent to which respondents knew the other persons was linearly connected to their desire to preserve social isolation. The most significant desire is to maintain separation among the least known individuals. Fear of transmission may substantially affect mental health than the illness itself, especially in younger persons. Numerous respondents said that the epidemic had impacted their relationships, particularly with close friends and family. This might result from psychological proximity, the provision of physical assistance, conflicting perspectives on COVID-19, or a combination of these and other variables.

Despite proactive safety measures, fears of contracting the virus at work remained high (especially for vulnerable respondents). This demonstrates contradiction regarding wanting to be close loved ones, despite awareness of the increased vulnerability of older persons to COVID-19. Additionally, respondents showed increased anxiety about the long-term effects of safety measures such as social isolation. As a result, the pandemic's mental health repercussions may outweigh concerns about virus danger, and the pandemic may arise as a result of more significant societal and economic shifts. 
Table 5: Social impacts of the COVID-19 pandemic

\begin{tabular}{|c|c|c|c|c|c|c|c|}
\hline \multirow[t]{2}{*}{ Statement } & \multicolumn{5}{|c|}{ Scale of Importance } & \multirow[t]{2}{*}{ Average } & \multirow[t]{2}{*}{ Level } \\
\hline & 1 & 2 & 3 & 4 & 5 & & \\
\hline $\begin{array}{l}\text { D1. The COVID-19 pandemic } \\
\text { has changed the way } \\
\text { people perceive the } \\
\text { importance of health in } \\
\text { comparison to the } \\
\text { economic growth of } \\
\text { Malaysia. }\end{array}$ & $\begin{array}{l}15 \\
(3.4 \%)\end{array}$ & $\begin{array}{l}20 \\
(4.6 \%)\end{array}$ & $\begin{array}{l}77 \\
(17.6 \%)\end{array}$ & $\begin{array}{l}158 \\
(36.2 \%)\end{array}$ & $\begin{array}{l}167 \\
(38.2 \%)\end{array}$ & 4.01 & 3 \\
\hline $\begin{array}{l}\text { D2. The food shortage has } \\
\text { increased during the } \\
\text { time of the COVID-19 } \\
\text { pandemic outbreak. }\end{array}$ & $\begin{array}{l}33 \\
(7.6 \%)\end{array}$ & $\begin{array}{l}108 \\
(24.7 \%)\end{array}$ & $\begin{array}{l}144 \\
(33.0 \%)\end{array}$ & $\begin{array}{l}107 \\
(24.5 \%)\end{array}$ & $\begin{array}{l}45 \\
(10.3 \%)\end{array}$ & 3.05 & 2 \\
\hline $\begin{array}{l}\text { D3. Social relationships } \\
\text { among family members } \\
\text { have gotten better as } \\
\text { people are always } \\
\text { concerned about each } \\
\text { other's health. }\end{array}$ & $\begin{array}{l}11 \\
(2.5 \%)\end{array}$ & $\begin{array}{l}18 \\
(4.1 \%)\end{array}$ & $\begin{array}{l}67 \\
(15.3 \%)\end{array}$ & $\begin{array}{l}158 \\
(36.2 \%)\end{array}$ & $\begin{array}{l}183 \\
(41.9 \%)\end{array}$ & 4.11 & 3 \\
\hline $\begin{array}{l}\text { D4. The COVID-19 pandemic } \\
\text { has affected people's } \\
\text { mental health. }\end{array}$ & $\begin{array}{l}36 \\
(8.2 \%)\end{array}$ & $\begin{array}{l}64 \\
(14.6 \%)\end{array}$ & $\begin{array}{l}119 \\
(27.2 \%)\end{array}$ & $\begin{array}{l}124 \\
(28.4 \%)\end{array}$ & $\begin{array}{l}94 \\
(21.5 \%)\end{array}$ & 3.40 & 2 \\
\hline $\begin{array}{l}\text { D5. The learning processes } \\
\text { at schools/universities } \\
\text { have been disrupted } \\
\text { due to the COVID-19 } \\
\text { pandemic. }\end{array}$ & $\begin{array}{l}10 \\
(2.3 \%)\end{array}$ & $\begin{array}{l}11 \\
(2.5 \%)\end{array}$ & $\begin{array}{l}49 \\
(11.2 \%)\end{array}$ & $\begin{array}{l}125 \\
(28.6 \%)\end{array}$ & $\begin{array}{l}242 \\
(55.4 \%)\end{array}$ & 4.32 & 3 \\
\hline $\begin{array}{l}\text { D6. The COVID-19 pandemic } \\
\text { has hindered people } \\
\text { from living healthy } \\
\text { lifestyles. }\end{array}$ & $\begin{array}{l}42 \\
(9.6 \%)\end{array}$ & $\begin{array}{l}96 \\
(22.0 \%)\end{array}$ & $\begin{array}{l}135 \\
(30.9 \%)\end{array}$ & $\begin{array}{l}99 \\
(22.7 \%)\end{array}$ & $\begin{array}{l}65 \\
14.9 \%)\end{array}$ & 3.11 & 2 \\
\hline $\begin{array}{l}\text { D7. The COVID- } 19 \text { pandemic } \\
\text { has resulted in limited } \\
\text { physical activities during } \\
\text { the time of the } \\
\text { outbreak. }\end{array}$ & $\begin{array}{l}17 \\
(3.9 \%)\end{array}$ & $\begin{array}{l}25 \\
(5.7 \%)\end{array}$ & $\begin{array}{l}69 \\
(15.8 \%)\end{array}$ & $\begin{array}{l}188 \\
(43.0 \%)\end{array}$ & $\begin{array}{l}138 \\
(31.6 \%)\end{array}$ & 3.93 & 3 \\
\hline $\begin{array}{l}\text { D8. The COVID-19 pandemic } \\
\text { has encouraged people } \\
\text { to consume a healthier } \\
\text { diet. }\end{array}$ & $\begin{array}{l}16 \\
(3.7 \%)\end{array}$ & $\begin{array}{l}40 \\
(9.2 \%)\end{array}$ & $\begin{array}{l}108 \\
(24.7 \%)\end{array}$ & $\begin{array}{l}155 \\
(35.5 \%)\end{array}$ & $\begin{array}{l}118 \\
(27.0 \%)\end{array}$ & 3.73 & 3 \\
\hline
\end{tabular}




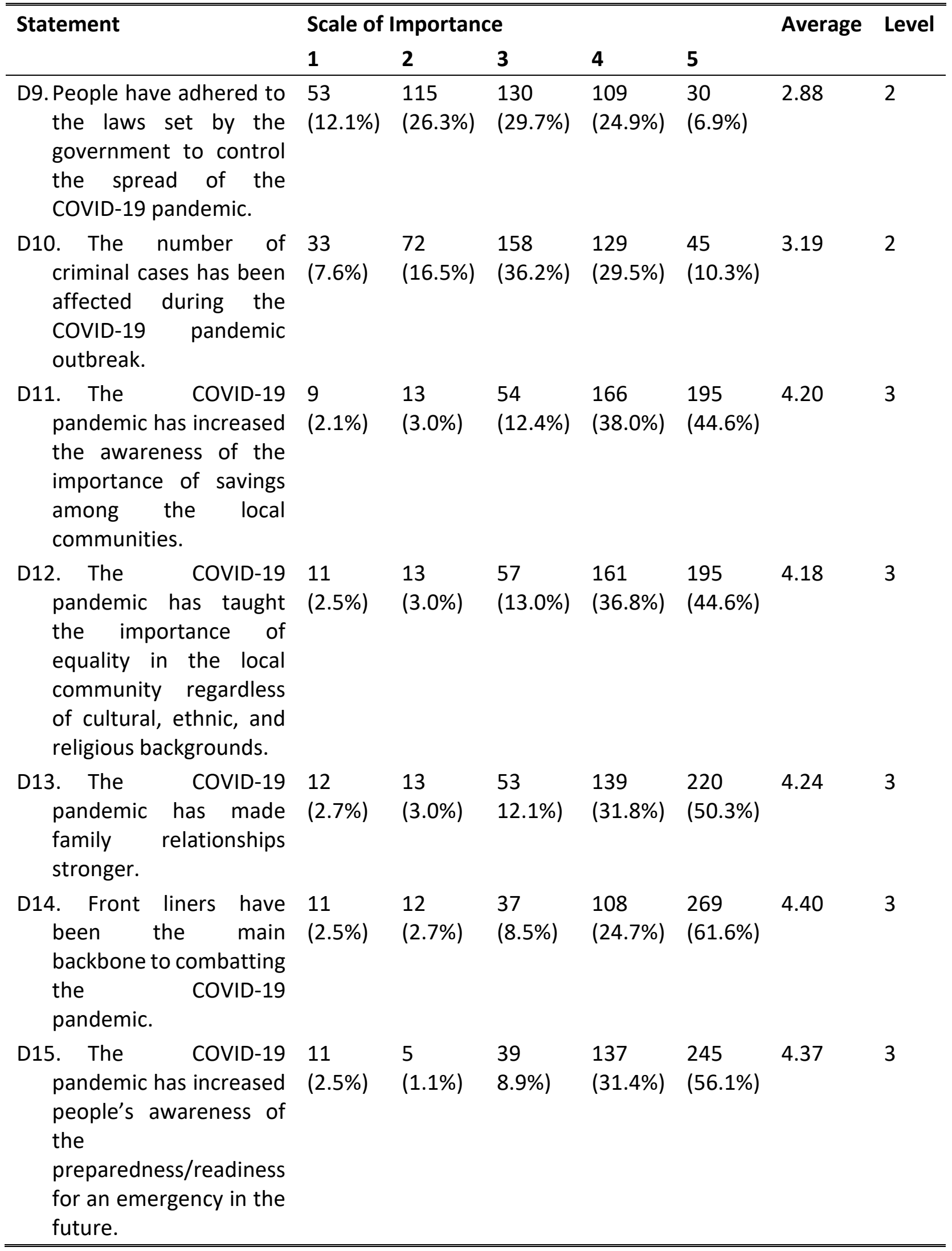




\begin{tabular}{|c|c|c|c|c|c|c|c|}
\hline \multirow[t]{2}{*}{ Statement } & \multicolumn{5}{|c|}{ Scale of Importance } & \multirow[t]{2}{*}{ Average } & \multirow[t]{2}{*}{ Level } \\
\hline & 1 & 2 & 3 & 4 & 5 & & \\
\hline $\begin{array}{l}\text { D16. The COVID-19 } \\
\text { pandemic has increased } \\
\text { awareness of digital } \\
\text { services or utilisation as } \\
\text { a result of the MCO. }\end{array}$ & $\begin{array}{l}10 \\
(2.3 \%)\end{array}$ & $\begin{array}{l}10 \\
(2.3 \%)\end{array}$ & $\begin{array}{l}43 \\
(9.8 \%)\end{array}$ & $\begin{array}{l}136 \\
(31.1 \%)\end{array}$ & $\begin{array}{l}238 \\
(54.5 \%)\end{array}$ & 4.33 & 3 \\
\hline $\begin{array}{l}\text { D17. The pandemic has } \\
\text { increased the } \\
\text { awareness of the } \\
\text { importance } \\
\text { transparent } \\
\text { communication of the } \\
\text { impacts of COVID-19. }\end{array}$ & $\begin{array}{l}10 \\
(2.3 \%)\end{array}$ & $\begin{array}{l}7 \\
(1.6 \%)\end{array}$ & $\begin{array}{l}39 \\
(8.9 \%)\end{array}$ & $\begin{array}{l}149 \\
(34.1 \%)\end{array}$ & $\begin{array}{l}232 \\
(53.1 \%)\end{array}$ & 4.34 & 3 \\
\hline $\begin{array}{l}\text { D18. The COVID-19 } \\
\text { pandemic has increased } \\
\text { the awareness of the } \\
\text { importance of voluntary } \\
\text { community services. }\end{array}$ & $\begin{array}{l}9 \\
(2.1 \%)\end{array}$ & $\begin{array}{l}9 \\
(2.1 \%)\end{array}$ & $\begin{array}{l}49 \\
(11.2 \%)\end{array}$ & $\begin{array}{l}155 \\
(35.5 \%)\end{array}$ & $\begin{array}{l}215 \\
(49.2 \%)\end{array}$ & 4.28 & 3 \\
\hline Overall mean & & & & & & 3.90 & 3 \\
\hline
\end{tabular}

*Levels of agreement: Low agreement (1): 1- 2.339, Medium agreement (2): 2.34-3.669, and High agreement (3): 3.67-5.00

A bivariate Pearson correlation analysis determined the relationships between the three COVID-19 pandemic consequences (See Table 6). The findings indicated a positive correlation between awareness of COVID-19's economic impact and awareness of COVID-19's environmental impact ( $r=0.602)$, suggesting a significant relationship, as per Cohen (1988). At a $99 \%$ level of confidence, the relationship was significant. The data indicate that as awareness of COVID-19's economic impact increases, so does awareness of its environmental impact. Following that, the findings indicated a positive correlation between knowledge of COVID-19's economic impact and awareness of COVID-19's social impact ( $r=0.545)$, implying a significant relationship, according to Cohen (1988). The relationship was significant at a $99 \%$ level of confidence. The finding implies that the greater awareness of COVID-19's economic impacts, the greater awareness of its social impacts.

In addition, the results found a positive relationship between the awareness of the COVID19 's environmental and social impacts ( $r=0.595)$, thus, suggesting a significant relationship, according to Cohen (1988). The relationship was significant at a $99 \%$ confidence level. The finding implies that the greater the awareness of COVID-19's environmental impacts, the greater the awareness of the social impacts. 
Table 6: Pearson correlation

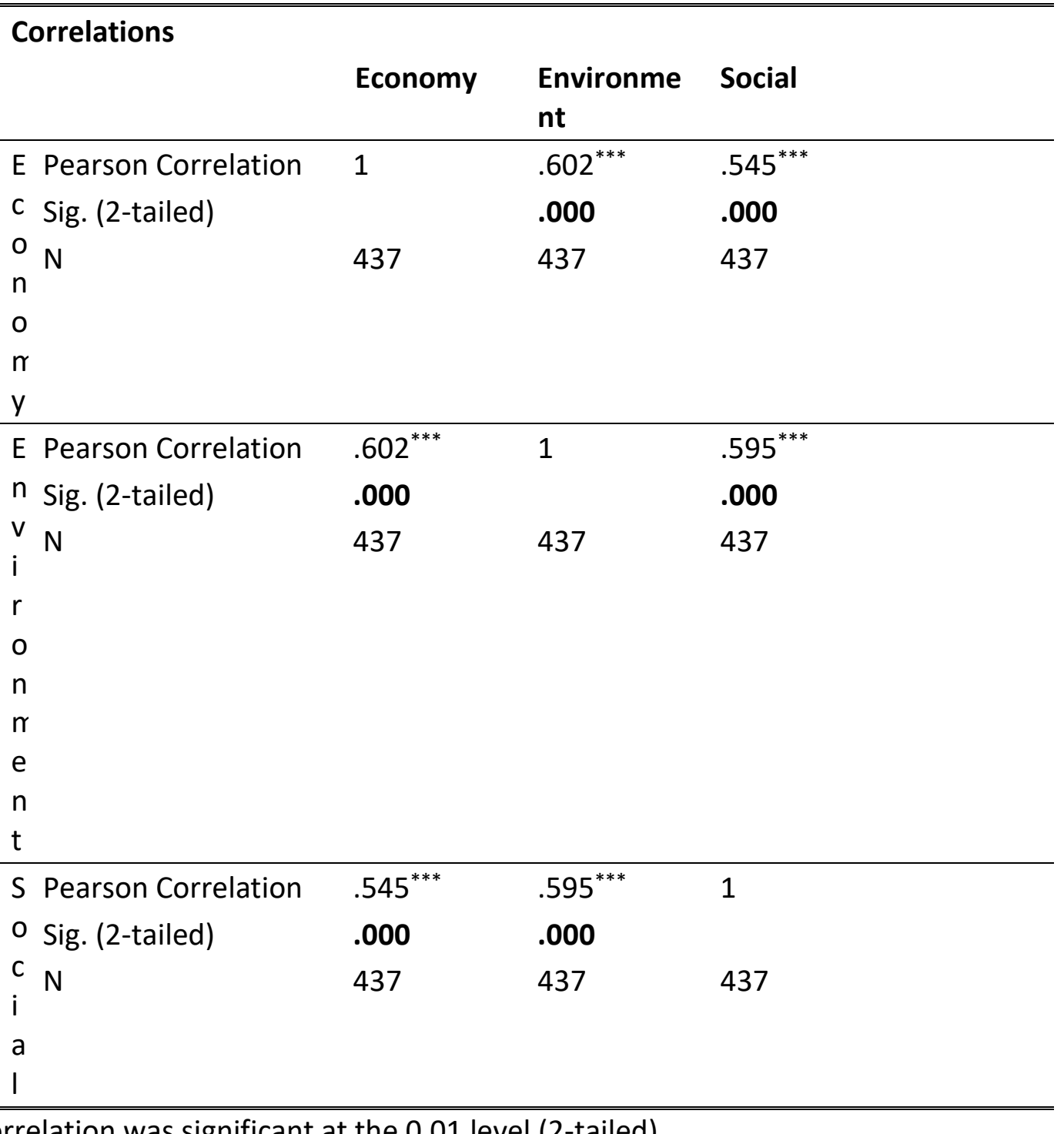

**. Correlation was significant at the 0.01 level (2-tailed).

One-way ANOVA tests were conducted on age groups, income groups, location of residence (urban, suburbs, and rural), and education groups with regard to their perceptions of the economic, environmental, and social impacts of the COVID-19 pandemic (see Table 7). There was a substantial disparity in perceptions of the economic impact of the COVID-19 pandemic across age groups at a $99 \%$ level of confidence. This indicated that various age groups had varying perceptions of the economic impacts. There were also no significant differences in their perceptions of social and environmental impacts. There was a substantial difference in economic impact at a $95 \%$ confidence level for the income groups. This suggests that perceptions vary according to income group. However, there were no significant differences in their perceptions of the social and environmental impacts across income groups, suggesting slight disparities in their perceptions. There was a substantial difference in respondents' views from different areas (urban, suburbs, and rural) and perceptions of economic impacts at a 99 per cent level of confidence. In contrast, there were no significant differences in their perceptions of social and environmental impacts across income groups. There were no significant variations between respondents' perceptions of economic, 
environmental, and social impacts across the education groups, as the p-value was above 0.05 .

Table 7: One-way ANOVA tests across age groups, income groups, residential locations, and education groups on awareness of COVID-19's economic, environmental, and social impacts

\begin{tabular}{|c|c|c|c|c|c|}
\hline \multicolumn{6}{|l|}{ ANOVA } \\
\hline & $\begin{array}{l}\text { Sum of } \\
\text { Squares }\end{array}$ & df & $\begin{array}{l}\text { Mean } \\
\text { Square }\end{array}$ & $\mathbf{F}$ & Sig. \\
\hline \multicolumn{6}{|l|}{ AGE } \\
\hline \multicolumn{6}{|c|}{$\begin{array}{l}\text { Age groups and } \\
\text { economics }\end{array}$} \\
\hline Among Groups & 5.675 & 3 & 1.892 & 5.424 & $.001 * * *$ \\
\hline Within Groups & 151.009 & 433 & .349 & & \\
\hline Total & 156.683 & 436 & & & \\
\hline \multicolumn{6}{|c|}{$\begin{array}{l}\text { Age groups and } \\
\text { environment }\end{array}$} \\
\hline Among Groups & 1.852 & 3 & .617 & 1.311 & .270 \\
\hline Within Groups & 203.886 & 433 & .471 & & \\
\hline Total & 205.738 & 436 & & & \\
\hline \multicolumn{6}{|c|}{$\begin{array}{l}\text { Age groups and social } \\
\text { aspect }\end{array}$} \\
\hline Among Groups & .193 & 3 & .064 & .212 & .888 \\
\hline Within Groups & 131.290 & 433 & .303 & & \\
\hline Total & 131.483 & 436 & & & \\
\hline \multicolumn{6}{|c|}{$\begin{array}{l}\text { Income groups and } \\
\text { economics }\end{array}$} \\
\hline Among Groups & 1.754 & 2 & .877 & 2.457 & $.047^{* *}$ \\
\hline Within Groups & 154.929 & 434 & .357 & & \\
\hline Total & 156.683 & 436 & & & \\
\hline \multicolumn{6}{|c|}{ Income groups and environment } \\
\hline Among Groups & 1.778 & 2 & .889 & 1.891 & .152 \\
\hline Within Groups & 203.960 & 434 & .470 & & \\
\hline Total & 205.738 & 436 & & & \\
\hline \multicolumn{6}{|c|}{ Income groups and social aspect } \\
\hline Among Groups & .984 & 2 & .492 & 1.635 & .196 \\
\hline Within Groups & 130.500 & 434 & .301 & & \\
\hline
\end{tabular}




\begin{tabular}{lllll}
\hline \hline ANOVA & $\begin{array}{l}\text { Sum of } \text { df } \\
\text { Squares }\end{array}$ & $\begin{array}{l}\text { Mean } \\
\text { Square }\end{array}$ & Sig. \\
\hline Total & 131.483 & 436 & & \\
\end{tabular}

LOCATION OF RESIDENCE (URBAN, SUBURBS, AND RURAL) WITH ECONOMICS

Location of residence (Urban, Suburbs, and rural) with economics

$\begin{array}{llllll}\text { Among Groups } & 6.421 & 2 & 3.211 & 9.273 & .000^{* *} \\ \text { Within Groups } & 150.262 & 434 & .346 & & \\ \text { Total } & 156.683 & 436 & & & \end{array}$

Location of residence (Urban, Suburbs, and rural) with an environment

$\begin{array}{llllll}\text { Among Groups } & .959 & 2 & .479 & 1.016 & .363 \\ \text { Within Groups } & 204.779 & 434 & .472 & & \\ \text { Total } & 205.738 & 436 & & & \end{array}$

Location of residence (Urban, Suburbs, and rural) with a social aspect

$\begin{array}{llllll}\text { Among Groups } & 1.413 & 2 & .706 & 2.357 & .096 \\ \text { Within Groups } & 130.071 & 434 & .300 & & \\ \text { Total } & 131.483 & 436 & & & \end{array}$

EDUCATION LEVEL

Education level and

Economics

$\begin{array}{llllll}\text { Among Groups } & 1.209 & 3 & .403 & 1.123 & .340 \\ \text { Within Groups } & 155.474 & 433 & .359 & & \\ \text { Total } & 156.683 & 436 & & & \end{array}$

Education level and environment

$\begin{array}{llllll}\text { Among Groups } & .732 & 3 & .244 & .516 & .672 \\ \text { Within Groups } & 205.005 & 433 & .473 & & \\ \text { Total } & 205.738 & 436 & & & \end{array}$

Education level and Social aspect

\begin{tabular}{llllll} 
Among Groups & .884 & 3 & .295 & .978 & .403 \\
Within Groups & 130.599 & 433 & .302 & & \\
Total & 131.483 & 436 & & & \\
\hline
\end{tabular}

** Significant at a 95\% level of confidence 


\section{Conclusion}

The purpose of this study was to assess the extent to which the public was aware of the economic, environmental, and social impacts of the COVID-19 pandemic. There were a total of 437 completed questionnaires. The statistical techniques used in the data analysis were both descriptive and inferential. The results suggested that respondents perceived a significant impact of the COVID-19 pandemic on Malaysia's economy, environment, and social aspects.

It is revealed that the pandemic has a negative impact on the economy and society through changes in personnel policies, inefficiencies in labour outputs, and higher corporate and government expenditure on health care programmes and safety measures. Additionally, participants reported a high level of insecurity, a reduction in employment, a decline in consumer spending, and overall business expenditures.

Regarding the significant findings and their implications for perceptions of economic impact awareness, respondents perceived that the COVID-19 pandemic had little effect on employment rates but significantly impacted SMEs. Moreover, the epidemic has had an impact on people's purchasing behaviour. Additionally, the COVID-19 epidemic has disrupted product supply systems. Furthermore, respondents acknowledged that their savings had been compromised. In response to the significant economic impact of the epidemic, the Malaysian government launched the Economic Stimulus Package 2020, which was required to boost startups. In addition, the Economic Stimulus Package was required to mitigate the harmful effects of the lack of revenue and liquidity on SMEs and generally disadvantaged households. Stimulus Packages will help both organisations and businesses to adhere to the limits and safety measures, enabling them to accelerate their recovery after the epidemic has subsided. Additionally, significant economic incentives should be explored soon after the pandemic subsides, while orders for movement limitations be eased where and when practicable in order to accelerate the speed of economic recovery.

As a result of extensive company closures and decreased productivity, the COVID-19 pandemic directly impacted income. Additionally, it has created a negative supply shock as a consequence of industrial productivity declines caused by global supply chain disruptions and site closures. During the outbreak, equities on Malaysia's Bursa Malaysia exchange plummeted as investors liquidated holdings in anticipation of the virus's expected economic effect on Malaysia and other developing stock markets until June 2020.

Furthermore, in terms of perceptions of environmental impact, COVID-19 has significantly facilitated environmentally friendly online work, and air quality has improved as a consequence of reduced transportation movement, which has a good effect on human health. COVID-19, on the other hand, boosted waste generation owing to a rise in medical waste and a surge in online purchasing, which necessitates wrapping. Additionally, throughout the pandemic, household electricity use soared. On this point, although the COVID-19 outbreak has wreaked havoc on communities and the economy, it has also resulted in a massive worldwide shutdown of industrial and manufacturing activity, benefiting the environment. The limitations have altered the public's behaviour. Reduced mobility has resulted in a considerable reduction in air pollution levels. On the social aspect, it was discovered that respondents did not believe there was sufficient compliance with the mechanisms in place to prevent the spread of the infection. A robust social protection system is critical for safeguarding employees, students, and vulnerable individuals and reducing 
future occurrences of similar tragedies. It would also be effective to provide basic insurance plans, job stability and to strengthen the public's capability to handle and combat such crises.

Thus, respondents' awareness of COVID-19's environmental impact indicated a cleaner environment was anticipated due to the pandemic, which may benefit human health. In addition, Malaysia is less affected by transmission-related air pollution emissions, material usage, and land-use change in the short and long terms. In the short term, farmland area (harvested area) stays almost unaltered, and the relatively quick rebound in food demand guarantees that land-use change remains very close to baseline values. This, together with the low effect on forestry, indicates that decreased economic activity may have a minor impact on biodiversity and environmental services. Thus, the COVID-19 outbreak and its associated responses have led to significant reductions in carbon dioxide and other air pollution in Malaysia, according to the findings of this study.

Concerning the societal impacts of COVID-19, respondents perceived that there was inadequate compliance with the virus-prevention measures in place. Almost every government globally has declared or considered introducing social distancing and sanitation measures to reduce Coronavirus contamination and mortality and reduce the burden on health care personnel.

The bivariate Pearson correlation analysis revealed a positive relationship between awareness of COVID-19's economic and environmental impact. Additionally, there was a positive relationship between awareness of the economic and the social impacts of COVID19. Furthermore, the findings indicated a positive correlation between awareness of COVID19 's environmental and social impacts. According to the study findings, the Malaysian government should increase national awareness of the current pandemic's social, environmental, and economic impacts. Numerous impacts have been noticed as the pandemic continues to spread over the globe. Moreover, the study evaluated the prospective influence of the literature search on pandemic studies and the present challenges encountered in constructing the research instrument.

However, considerable transformation is necessary for tourism to make a meaningful contribution to global GHG emission reductions. The time after the COVID-19 pandemic is hopefully defined by sustained economic, sociological, and environmental recovery. It will be critical to maintain the current low level of GHG emissions and achieve economic recovery throughout this period. Additionally, any recovery must be financially and socially sustainable for tourism stakeholders.

Using Pearson correlation, this study evaluated Malaysians' perceptions of the impact of COVID-19. As a consequence, a recommendation was presented for further investigation. Numerous approaches, such as the moving average method, exponential smoothing techniques, and Holt's methods, may be utilised to calculate the forecasting method's minimum error.

Additionally, some respondents stated that the pandemic had impacted their relationships, particularly with close ones. This might result from psychological proximity, the provision of physical assistance, conflicting perspectives on COVID-19, or a combination of these and other variables. Additionally, Malaysians would likely maintain social distance from close friends and family in the future, given that most respondents expressed anxiety about social distancing. Mental health was also mentioned as a significant societal concern. Additional 
study is required to ascertain how attitudes may differ due to psychological anxiety of contracting the virus and spreading it; disapproval; social and mental health concerns; and the availability of personal protective equipment or occupational practicality.

According to the findings of this study, policymakers and business managers may design mitigation techniques for COVID-19's adverse effects across a variety of activities. Additionally, a pandemic might result in labour shortages, income loss as a consequence of stockpiling and inefficient storage methods, order cancellations, transportation difficulties, and concerns about food safety. Processing and packaging may also be influenced by decreased or discontinued production, employee layoffs, the manufacture and sale of less safe and low-quality items, a lack of working capital, the absence or inability of essential technical employees, and psychological effects. The measures include enhancements to more agile systems across the food supply chain, including production, handling and storage, processing and packaging, distribution and marketing, and consumption. The pandemic has been found to have a negative impact on Malaysian healthcare and food commodities. Thus, specific procedures are required to handle and manage the supply chain and storage level effectively.

Initiatives should prioritise ensuring the availability and timely delivery of items that were limited during the pandemic at reasonable costs to minimise supply interruptions for agricultural inputs. Employee shortages may be addressed by strategically moving employees to labour-intensive manufacturing zones. Additionally, it is vital to attract urban and suburban returnees. It is crucial to support technology innovation in the long term to operate more agile supply chain systems. Distribution and marketing should be strengthened by empowering producers and consumer cooperatives, regulating and monitoring prices, increasing food availability through imports while likely reducing exports of staple food commodities and food aid, and improving vulnerable community access to food through the establishment of cash for work schemes. Finally, several alternative initiatives and policies should be identified to promote socialisation and identify the pandemic's social impacts. The government undoubtedly plays a vital role in encouraging socialisation and connecting public policy with civic action to catalyse change in response to a range of social challenges. The government might take a proactive role in promoting public dialogue and understanding about the societal challenges resulting from the COVID-19 outbreak. Government and civil society players may work together to enhance public awareness of and action on critical social and environmental issues.

\section{Acknowledgement}

I would like to express my heartfelt appreciation to all co-authors and proofreaders of this paper for their contributions to its quality.

\section{References}

Adnan, N., \& Nordin, S. M. (2021). How COVID 19 effect Malaysian paddy industry? Adoption of green fertiliser a potential resolution. Environment, development and sustainability, 23(6), 8089-8129.

Alam, J. (2020). Buying Behavior Under Coronavirus Disease (COVID-19) Pandemic Situation: A Online Perspective Case in Bangladeshi Shoppers. Chinese Business Review, 19(3), 8290. https://doi.org/https://doi.org/10.17265/1537-1506/2020.03.002 
Ali, Q., Parveen, S., Yaacob, H., Zaini, Z., \& Sarbini, N. A. (2021). COVID-19 and dynamics of environmental awareness, sustainable consumption and social responsibility in Malaysia. Environmental Science and Pollution Research, 1-20.

Amon, J. J., \& Wurth, M. (2020). A Virtual Roundtable on COVID-19 and Human Rights with Human Rights Watch Researchers. Health and Human Rights, 22(1), 399-413. https://doi.org/https://doi.org/10.0000/www.ncbi.nlm.nih.gov/PMC7348426

Anjum, N. (2020). Good in The Worst: COVID-19 Restrictions and Ease in Global Air Pollution. Preprints, April. https://doi.org/10.20944/preprints202004.0069.v1

Aw, S. B., Teh, B. T., Ling, G. H. T., Leng, P. C., Chan, W. H., \& Ahmad, M. H. (2021). The COVID19 Pandemic Situation in Malaysia: Lessons Learned from the Perspective of Population Density. International Journal of Environmental Research and Public Health, 18(12), 6566.

Baker, S. R., Farrokhnia, R. A., Meyer, S., Pagel, M., \& Yannelis, C. (2020). How does household spending respond to an epidemic? consumption during the 2020 COVID-19 pandemic. In Review of Asset Pricing Studies (Vol. 10, Issue 4). Oxford University Press. https://doi.org/10.1093/rapstu/raaa009

Barlas, S. (2013). FDA Strategies to Prevent and Respond to Drug Shortages. Pharmacy and Therapeutics, 38(5), 261-263. https://www.ncbi.nlm.nih.gov/pmc/articles/PMC3737981/

Bartik, A. W., Bertrand, M., Cullen, Z., Glaeser, E. L., Luca, M., \& Stanton, C. (2020). The impact of COVID-19 on small business outcomes and expectations. In Proceedings of the National Academy of Sciences of the United States of America (Vol. 117, Issue 30, pp. 17656-17666). National Acad Sciences. https://doi.org/10.1073/pnas.2006991117

Bastos, P. (2020). Exposure of belt and road economies to China trade shocks. In Journal of Development Economics (Vol. 145). The World Bank. https://doi.org/10.1016/j.jdeveco.2020.102474

Bavel, J. J. V., Baicker, K., Boggio, P. S., Capraro, V., Cichocka, A., Cikara, M., Crockett, M. J., Crum, A. J., Douglas, K. M., Druckman, J. N., Drury, J., Dube, O., Ellemers, N., Finkel, E. J., Fowler, J. H., Gelfand, M., Han, S., Haslam, S. A., Jetten, J., ... Willer, R. (2020). Using social and behavioural science to support COVID-19 pandemic response. Nature Human Behaviour, 4(5), 460-471. https://doi.org/10.1038/s41562-020-0884-z

Breitenbach, M. C., Ngobeni, V., \& Aye, G. C. (2020). The First 100 days of COVID-19 Coronavirus - How Efficient did Country Health systems Perform to Flatten the Curve in the First Wave? Munich Personal RePEC Archive Efficiency, 101440, 1-25. https://mpra.ub.uni-muenchen.de/101440/

Briscese, G., Lacetera, N., Macis, M., \& Tonin, M. (2020). Expectations, reference points, and compliance with COVID-19 social distancing measures. In National Bureau of Economic Research (Vol. 21, Issue 1). National Bureau of Economic Research. https://doi.org/10.3386/w26916

Calma, J. (2020). The COVID-19 Pandemic Is Generating Tons of Medical Waste: Sanitation Workers Need Personal Protective Equipment Too. The Verge. https://www.theverge.com/2020/3/26/21194647/the-covid-19-pandemic-isgenerating-tons-of-medical-waste

Cascella, M., Rajnik, M., Cuomo, A., Dulebohn, S. C., \& Di Napoli, R. (2020). Features, Evaluation and Treatment Coronavirus (COVID-19). In StatPearls. StatPearls and Publishing. http://www.ncbi.nlm.nih.gov/pubmed/32150360 
Cassepp-Borges, V., Balbinotti, M. A., \& Teodoro, M. L. (2010). Content translation and validation: A proposal for instrument adaptation. Psychol. Instrum. Fundam. Pract, 2010, 506-520.

Chatzittofis, A., Karanikola, M., Michailidou, K., \& Constantinidou, A. (2021). Impact of the COVID-19 pandemic on the mental health of healthcare workers. International Journal of Environmental Research and Public Health, 18(4), 1-8. https://doi.org/10.3390/ijerph18041435

Christensen, L. B., Johnson, R. B., \& Turner, L. A. (2014). Research Methods, Design, and Analysis. In Pearson (12th ed.). Saddle River, NJ: Pearson.

https://www.pearson.com/uk/educators/higher-education-

educators/program/Christensen-Research-Methods-Design-and-Analysis-Global-

Edition-12th-Edition/PGM1080385.html

Cohen, J. (1988). Statistical Power Analysis for the Behavioral Sciences. In Statistical Power Analysis for the Behavioral Sciences (2nd ed.). Lawrence Erlbaum Associates. https://doi.org/10.4324/9780203771587

Coibion, O., Gorodnichenko, Y., \& Weber, M. (2020). The cost of the covid-19 crisis: Lockdowns, macroeconomic expectations, and consumer spending. National Bureau of Economic Research. https://doi.org/10.3386/w27141

Driggin, E., Madhavan, M. V, Bikdeli, B., Chuich, T., Laracy, J., Biondi-Zoccai, G., Brown, T. S., Der Nigoghossian, C., Zidar, D. A., \& Haythe, J. (2020). Cardiovascular considerations for patients, health care workers, and health systems during the COVID-19 pandemic. Journal of the American College of Cardiology, 75(18), 2352-2371. https://doi.org/10.1016/j.jacc.2020.03.031

Duan, L., \& Zhu, G. (2020). Psychological interventions for people affected by the COVID-19 epidemic. The Lancet Psychiatry, 7(4), 300-302. https://doi.org/10.1016/s22150366(20)30073-0

Dzulkifly, D. (2020). Tourism industry hit hardest by Covid-19, faces RM3.37b loss. Malay Mail. https://www.malaymail.com/news/malaysia/2020/03/13/muhyiddin-tourismindustry-hithard- By-covid-19-to-loserm3.37b-while-gdp-s/1846323

Edoho, J. G., \& Mfon, U. Y. (2020). Assessing the socio-economic effect of the coronavirus pandemic. Covid 19. https://reliefweb.int/sites/reliefweb.int/files/resources/IOM Socio-economic impact of COVID-19.pdf

Everitt, B. S.; Skrondal, A. (2010), The Cambridge Dictionary of Statistics, Cambridge University Press.

Farique, M. A. M., \& Fauzi, M. A. M. (2021). Implikasi Pandemik COVID-19 terhadap Ekonomi Global dan Ekonomi Malaysia. International Journal of Interdisciplinary and Strategic Studies, 2(1), 122-129.

Fernandes, N. (2019). Economic Effects of Coronavirus Outbreak (\{COVID\}-19) on the World Economy. SSRN 3557504, 291-305. https://doi.org/10.31410/tmt.2019.291

Financial Times. (2020). Real-time data show virus hit to global economic activity. Financial Times. https://www.ft.com/content/d184fa0a-6904-11ea-800d-da70cff6e4d3

Foo, L. P., Chin, M. Y., Tan, K. L., \& Phuah, K. T. (2020). The impact of COVID-19 on tourism industry in Malaysia. Current Issues in Tourism.

https://doi.org/10.1080/13683500.2020.1777951

Gillingham, K. T., Knittel, C. R., Li, J., Ovaere, M., \& Reguant, M. (2020). The Short-run and Long-run Effects of Covid-19 on Energy and the Environment. Joule, 4(7), 1337-1341. https://doi.org/10.1016/j.joule.2020.06.010 
Global Carbon Project. (2019). Global Carbon Budget 2012: An annual update of the global carbon budget and trends. Carbon Budget 2019.

http://www.globalcarbonproject.org/carbonbudget/index.htm

Gunnell, D., Appleby, L., Arensman, E., Hawton, K., John, A., Kapur, N., Khan, M., O'Connor, R. C., Pirkis, J., Caine, E. D., Chan, L. F., Chang, S. Sen, Chen, Y. Y., Christensen, H., Dandona, R., Eddleston, M., Erlangsen, A., Harkavy-Friedman, J., Kirtley, O. J., ... Yip, P. S. (2020). Suicide risk and prevention during the COVID-19 pandemic. In The Lancet Psychiatry (Vol. 7, Issue 6, pp. 468-471). Elsevier. https://doi.org/10.1016/S2215-0366(20)301711

Holmes, E. A., O'Connor, R. C., Perry, V. H., Tracey, I., Wessely, S., Arseneault, L., Ballard, C., Christensen, H., Cohen Silver, R., Everall, I., Ford, T., John, A., Kabir, T., King, K., Madan, I., Michie, S., Przybylski, A. K., Shafran, R., Sweeney, A., ... Bullmore, E. (2020). Multidisciplinary research priorities for the COVID-19 pandemic: a call for action for mental health science. The Lancet Psychiatry, 7(6), 547-560. https://doi.org/10.1016/S2215-0366(20)30168-1

Hundleby, J. D., \& Nunnally, J. (1968). Psychometric Theory. American Educational Research Journal, 5(3), 431. https://doi.org/10.2307/1161962

International Labor Organization (2020). The Impact of COVID-19 on the Tourism Sector.

Kaplan, J., Frias, L., \& Johnson, M. (2020). Our ongoing list of how countries are reopening, and which ones remain under lockdown. Business Insider.

https://www.businessinsider.nl/countries-on-lockdown-coronavirus-italy-2020-3/

Karim, W., Haque, A., Anis, Z., \& Ulfy, M. A. (2020). The Movement Control Order (MCO) for COVID-19 Crisis and its Impact on Tourism and Hospitality Sector in Malaysia. International Tourism and Hospitality Journal, 3(2), 1-7. https://doi.org/10.37227/ithj2020-02-09

Khatib, S. F., \& Nour, A. N. I. (2021). The impact of corporate governance on firm performance during the COVID-19 pandemic: evidence from Malaysia. Journal of Asian Finance, Economics and Business, Forthcoming.

Khazaei, H. (2020). Integrating cognitive antecedents to utaut model to explain adoption of blockchain technology among malaysian smes. International Journal on Informatics Visualization, 4(2), 85-90. https://doi.org/10.30630/joiv.4.2.362

Khazaei, H., \& Tareq, M. A. (2021). Moderating effects of personal innovativeness and driving experience on factors influencing adoption of BEVs in Malaysia: An integrated SEMBSEM approach. Heliyon, e08072.

Maharaj, S., \& Kleczkowski, A. (2012). Controlling epidemic spread by social distancing: do it well or not at all. BMC Public Health, 12(1), 679. https://doi.org/10.1186/1471-245812-679

Mark, E., Domingo, J. R. S., \& Singh, N. (2021). One Year on, the Centrality of Politics in Malaysia's COVID-19 Crisis. Southeast Asian Affairs, 2021(1), 185-202.

McKibbin, W. J., \& Fernando, R. (2020). The Global Macroeconomic Impacts of COVID-19: Seven Scenarios. SSRN Electronic Journal, 20(2), 1-30. https://doi.org/10.2139/ssrn.3547729

Merchant, R. M., \& Lurie, N. (2020). Social Media and Emergency Preparedness in Response to Novel Coronavirus. In JAMA - Journal of the American Medical Association (Vol. 323, Issue 20, pp. 2011-2012). American Medical Association. https://doi.org/10.1001/jama.2020.4469

Mourad, M. (2016). Recycling, recovering and preventing "food waste": Competing solutions 
for food systems sustainability in the United States and France. Journal of Cleaner Production, 126, 461-477. https://doi.org/10.1016/j.jclepro.2016.03.084

Najah, A., Teo, F. Y., Chow, M. F., Huang, Y. F., Latif, S. D., Abdullah, S., ... \& El-Shafie, A. (2021). Surface water quality status and prediction during movement control operation order under COVID-19 pandemic: Case studies in Malaysia. International Journal of Environmental Science and Technology, 18(4), 1009-1018.

Obi, S. E., Yunusa, T., Ezeogueri-Oyewole, A. N., Sekpe, S. S., Egwemi, E., \& Isiaka, A. S. (2020). The Socio-Economic Impact of Covid-19 on The Economic Activities of Selected States in Nigeria. Indonesian Journal of Social and Environmental Issues (IJSEI), 1(2), 39-47.

Patrício Silva, A. L., Prata, J. C., Walker, T. R., Duarte, A. C., Ouyang, W., Barcelò, D., \& RochaSantos, T. (2021). Increased plastic pollution due to COVID-19 pandemic: Challenges and recommendations. In Chemical Engineering Journal (Vol. 405, p. 126683). Elsevier. https://doi.org/10.1016/j.cej.2020.126683

Perroca, M. G., \& Gaidzinski, R. R. (1998). A system of patient classification: construction and validation of an instrument. Revista da Escola de Enfermagem da USP, 32(2), 153-168.

Ramli, M. W., \& Jamri, M. H. (2021). The impact of COVID-19 pandemic: A closer look at the night market traders' experience in Penang, Malaysia. International Journal of Academic Research in Business \& Social Sciences, 11(1), 741-760.

Rasheed, R., Rizwan, A., Javed, H., Sharif, F., \& Zaidi, A. (2021). Socio-economic and environmental impacts of COVID-19 pandemic in Pakistan-an integrated analysis. Environmental Science and Pollution Research, 28(16), 19926-19943.

Rousseau, S., \& Deschacht, N. (2020). Public Awareness of Nature and the Environment During the COVID-19 Crisis. Environmental and Resource Economics, 76(4), 1149-1159. https://doi.org/10.1007/s10640-020-00445-w

Seth, S., \& Housseini, B. (2014). Robustness Analysis and Statistical Inference.

Schanes, K., Dobernig, K., \& Gözet, B. (2018). Food waste matters - A systematic review of household food waste practices and their policy implications. Journal of Cleaner Production, 182, 978-991. https://doi.org/10.1016/j.jclepro.2018.02.030

Shah, A. U. M., Safri, S. N. A., Thevadas, R., Noordin, N. K., Rahman, A. A., Sekawi, Z., Ideris, A., \& Sultan, M. T. H. (2020). COVID-19 outbreak in Malaysia: Actions taken by the Malaysian government. International Journal of Infectious Diseases, 97, 108-116. https://doi.org/10.1016/j.ijid.2020.05.093

Shammi, M., Bodrud-Doza, M., Islam, A. R. M. T., \& Rahman, M. M. (2020). COVID-19 pandemic, socio-economic crisis and human stress in resource-limited settings: a case from Bangladesh. Heliyon, 6(5), e04063.

Singh, V., \& Mishra, V. (2021). Environmental impacts of coronavirus disease 2019 (COVID19). Bioresource Technology Reports, 100744.

Smith, E. (2020). Global stocks head for worst week since financial crisis on coronavirus fears. 2020. https://www.cnbc.com/2020/02/28/global-stocks-head-for-worst-week-sincefinancial-crisis-on-coronavirus-fears.html

Straka, W., Kondragunta, S., Wei, Z., Zhang, H., Miller, S. D., \& Watts, A. (2021). Examining the economic and environmental impacts of covid-19 using earth observation data. Remote Sensing, 13(1), 5.

Sumner, A., Hoy, C., \& Ortiz-Juarez, E. (2020). Estimates of the Impact of COVID-19 on Global Poverty. United Nations University World Institute for Development Economics Research. https://doi.org/10.35188/unu-wider/2020/800-9 
Tahajuddin, S., \& Sulaiman, N. N. (2021). Malaysian government choice of fiscal and monetary policies during covid-19 pandemic: Preliminary insight. Int I Advance Engineer Manage, 3(1), 248-53.

The World Tourism Organization (2020). Impact Assessment of the COVID-19 Outbreak on International

Todorovic, J., Piperac, P., \& Terzic-Supic, Z. (2020). Emergency management, mitigation for COVID-19 and the importance of preparedness for future outbreaks. International Journal of Health Planning and Management, 35(5), 1274-1276. https://doi.org/10.1002/hpm.3011

Tourism. Available online: https://www.unwto.org/impact-assessment-of-the-covid-19-

Urban, R. C., \& Nakada, L. Y. K. (2021). COVID-19 pandemic: Solid waste and environmental impacts in Brazil. Science of the Total Environment, 755, 142471.

WHO. (2020). Implications for infection prevention precautions. Transmission of SARS-CoV-2. https://www.who.int/news-room/commentaries/detail/transmission-of-sars-cov-2implications-for-infection-prevention-precautions.

Xu, X. W., Wu, X. X., Jiang, X. G., Xu, K. J., Ying, L. J., Ma, C. L., Li, S. B., Wang, H. Y., Zhang, S., Gao, H. N., Sheng, J. F., Cai, H. L., Qiu, Y. Q., \& Li, L. J. (2020). Clinical findings in a group of patients infected with the 2019 novel coronavirus (SARS-Cov-2) outside of Wuhan, China: Retrospective case series. The BMJ, 368, m606. https://doi.org/10.1136/bmj.m606

Zambrano-Monserrate, M. A., Ruano, M. A., \& Sanchez-Alcalde, L. (2020). Indirect effects of COVID-19 on the Environment. Science of the Total Environment, 728, 138813. https://doi.org/10.1016/j.scitotenv.2020.138813

Zubair, F., \& Shamsudin, M. F. (2021). Impact of Covid-19 on Tourism and Hospitality Industry of Malaysia. Journal of Postgraduate Current Business Research, 6(1), 6-6. 